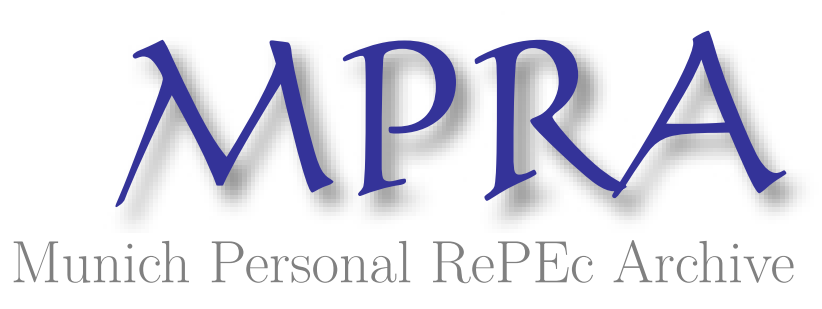

\title{
Targeting the real exchange rate: Theory and evidence
}

Reinhart, Carmen and Calvo, Guillermo and Vegh, Carlos

University of Maryland, College Park, Department of Economics

1994

Online at https://mpra.ub.uni-muenchen.de/13412/

MPRA Paper No. 13412, posted 15 Feb 2009 08:43 UTC 


\section{IMF WORKING PAPER}

(c) 1994 International Monetary Fund
This is a Working Paper and the author would weloome any comments on the present text. Citations should refer to a Working Paper of the International Monetary Fund, mentioning the author, and the date of issuance. The views expressed are those of the author and do nol necessarily represent those of the Fund.

WP $/ 94 / 22$

INTERNATIONAL MONETARY FUND

Research Department

Targeting the Real Exchange Rate: Theory and Evidence $1 /$

Frepared by Guillermo A. Calvo, Carmen M. Reinhart, and Carlos A. Végh

February 1994

\section{Abstract}

This paper presents a theoretical and empirical analysis of policies aimed at setting a more depreciated level of the real exchange rate. An intertemporal optimizing model suggests that, in the absence of changes in fiscal policy, a more depreclated level of the real exchange can only be attained temporarily. This can be achieved by means of higher inflation and/or higher real interest rates, depending on the degree of capital mobility. Evidence for Braz1l, Chile, and Colombia supports the model's prediction that undervalued real exchange rates are associated with higher inflation.

JEL Classification Numbers:

E52, F40

1/ This paper was prepared for the Sixth InterAmerican Seminar on Economics, held in Caracas, May 28-29, 1993, and will be published in a special issue of the Journal of Developments Economics. We are grateful to Miguel Kiguel, Saul Lizondo, Peter Montiel, Jonathan Ostry, Jorge Roldos, Andrés Velasco, Sweder van Wijnbergen, and seminar participants at Caracas, the University of Montreal, the 1993 Meetings of the Latin American Econometric Society (Tucuman, Argentina), and the International Monetary Fund for helpful comments and suggestions. 
II. Mode1 6

1. Perfect capital mobility 9

2. No capital mobility 11

III. Simulatin of the Model $\quad 15$

1. Perfect capital mobility 16

2. No capital mobility 20

IV. Empirical Implications $\quad 22$

1. Temporary shocks to the real exchange rate 22

2. Inflation and the real exchange rate 26

3. Implications of other models 28

V. Final Remarks $\quad 31$

Text Tables

1. Nominal Interest Rates to Generate a Given Depreciation 19

2. Real Interest Rate Needed to Generate a Given Depreciation 21

3. The Unit Root Tests 1979:II-1992:II

4. $1 / \mathrm{k}$ Times the Variance of $k$-differences of the Real Real Exchange Rate 25

5. Pairwise Correlations 1979:IV-1992:2 27

6. Cointegration Tests for the Real Exchange Rate, the

\footnotetext{
Inflation Tax, and Real GDP

Al. Beveridge-Nelson Decompositions of the Real Exchange Rate
}

Figures

1. Nominal and PPP Exchange Rates 2a

2. Real Effective Exchange Rates and Inflation 2b

3. Effects of Real Exchange Rate Targeting 10a

4. Temporary Component of Real Exchange Rate and Inflation 26a

A1. Real Exchange Rates: Trends and Cycles 34a

Appendix I

1. Derivation of some expressins in the text 33

2. Trend-cycle decomposition and the "economic fundaments" 33

Appendix Table

A1. Beveridge-Nelson Decompositions of the Real Exchange Rate 35 


\section{Introduction}

In an open economy, either the money supply or the nominal exchange rate can serve as a nominal anchor. Such an anchor is usually viewed as a necessary condition for macroeconomic stability since, at least in the long run, all nominal variables will converge to the pre-set rate of growth of either the money supply or the exchange rate. Assuming that appropriate fiscal and microeconomic policies are in place, the price stability brought about by a nominal anchor should ensure that the economy achieves long-run economic growth.

In practice, however, such a "neo-classical" view of policymaking is not universally accepted. Policymakers are not always content, especially in the short-run, with targeting nominal variables such as the exchange rate or the money supply. After all, the reasoning goes, if one is really interested in the behavior of real variables which have a direct bearing on growth (such as the real exchange rate or real interest rates), why not bypass nominal targets and simply try to set those variables at their desired levels? Thus, in spite of dire warnings from neo-classically inclined economists about the perils of losing the nominal anchor, policymakers have time and time again pursued real targets in implementing monetary and exchange rate policy.

Since the real exchange rate is a key relative price in any open economy, it is probably the most popular real target, at least in developing countries. 1/ By definition, then, a policy of "real exchange rate targeting" aims at controlling the level of the real exchange rate, either in an effort to keep it at a constant level in the face of domestic or external shocks, or achieve a different (usually more depreciated) level.

Diverse circumstances lead policymakers to engage in real exchange rate targeting. One of the most common reasons is the desire to index the nominal rate to the price level in an effort to avoid losses in competitiveness. Such policies are usually referred to as "purchasing power parity (PPP) rules." An early example is Brazil, where such a policy was adopted in August 1968 (Bacha (1979)). 2/ According to this rule, the exchange rate was changed by small percentages at irregular intervals of time (ten to fifty days), depending on the inflation differential between Brazil and the United States. With occasional deviations (due, for example, to changes in terms of trade and short-lived stabilization programs), Brazil has been following PPP rules ever since, even if such rules have not always been made explicit. This is illustrated (beginning in 1978) in Figure 1,

1/ It is certainly not the only one. Chile, for instance, has also used an interest rate on an indexed bond (i.e., a real interest rate) as its main policy instrument since 1985 (see Fontaine (1991)).

2/ According to Williamson (1981), Chile was the first country to adopt a PPP rule in 1965 (see French-Davis (1981)). 
which plots the behavior of the actual nominal exchange rate alongside the nominal exchange rate that would be consistent with a PPP rule. $1 /$

Chile arguably provides the most consummate example of a PPP rule. In July 1986, an exchange rate band was established whose central parity is adjusted at daily intervals according to a schedule based on the inflation rate during the previous month minus the estimated world inflation rate. Remarkably enough, there were no deviations from this rule until January 1992, when renewed pressures towards nominal appreciation of the peso steming from capital inflows led to a revaluation of 5 percent. The Chilean PPP rule can be clearly seen in Figure 1, starting in mid-1985. Following a sharp real devaluation during 1985, Colombia also followed a PPP rule during the period $1986-1990$, as can be seen in Figure 1. 2/

A second example of real exchange rate targeting consists of policies designed to achieve a more depreciated level of the real exchange rate. Chile, for instance, pursued a very aggressive policy of nominal devaluation during the period June 1982-June 1985, making a point of devaluing the domestic currency by rates that far exceeded the rate of inflation in order to engineer a substantial real depreciation (Edwards (1991)). As a result, in July 1985, the real exchange rate had almost doubled with respect to its May 1982 level (see Figure 2). 3 / Similarly, during 1985 Colombia devalued the domestic currency by substantial amounts, which led to a real depreciation of about 50 percent (Figure 2).

For all its practical and policy relevance, there is relatively little analytical work, and even less econometric work, on real exchange rate targeting. Adams and Gros (1986) were among the first to formally ask the two questions which, in our view, are key in analyzing real exchange rate

1/ The PPP exchange rate was computed as the ratio of the domestic CPI to that of the United States, and based by giving it the same value as the actual exchange in 78.01 for Brazil, 85.07 for Chile, and 86.01 for Colombia. (The United States inflation is used for simplicity; more comprehensive indices could be used.) In the case of Brazil, the base date coincides with the beginning of the sample; in the case of Chile and Colombia, the base date marks the beginning of a period during which a PPP rule was in effect (see below).

2/ In work in progress, we have analyzed these episodes in detail, and provided econometric evidence on the existence of PPP rules. Specifically, using monthly data we test for Granger-causality between inflation and the nominal exchange rate. As expected, we find that during the periods in which a PPP rule was in effect in both Chile and Colombia, the rate of devaluation was Granger-caused by inflation. In Brazil, considering the whole sample with the exception of the Cruzado and Collor plans, inflation also Granger-causes the rate of devaluation.

3/ Note that in Figure 2, a rise in the real exchange rate index indicates real depreciation. 
Figure 1. Nominal and PPP Exchange Rates

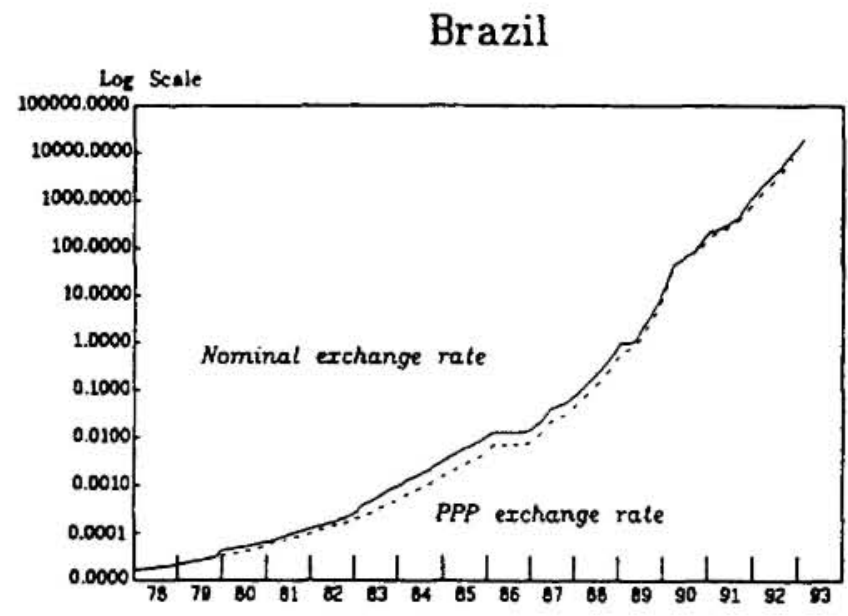

\section{Chile}

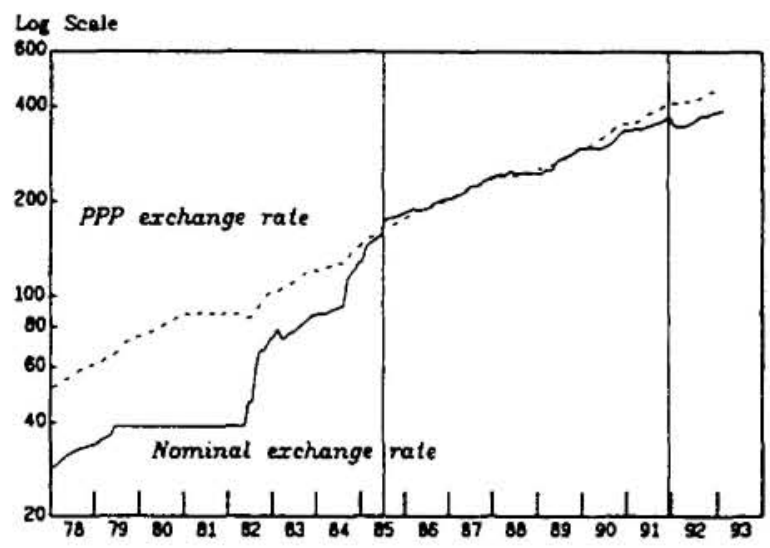

Colombia

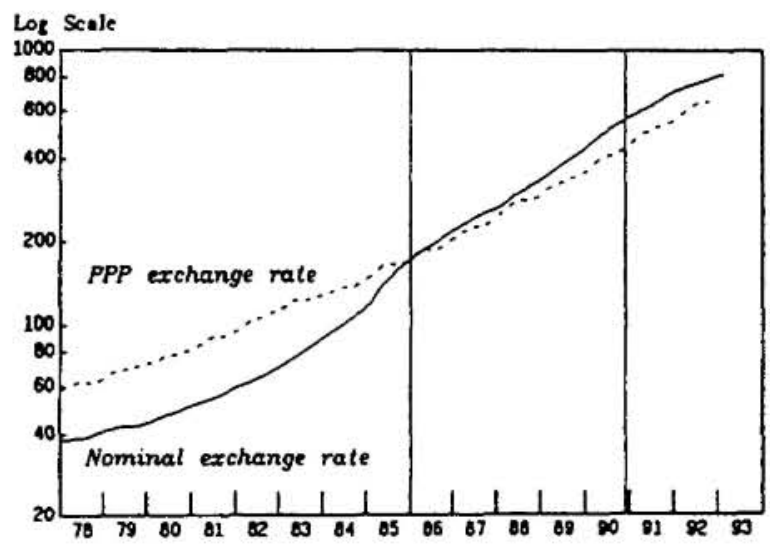



Figure 2. Real Effecitve Exchange Rates and Inflation
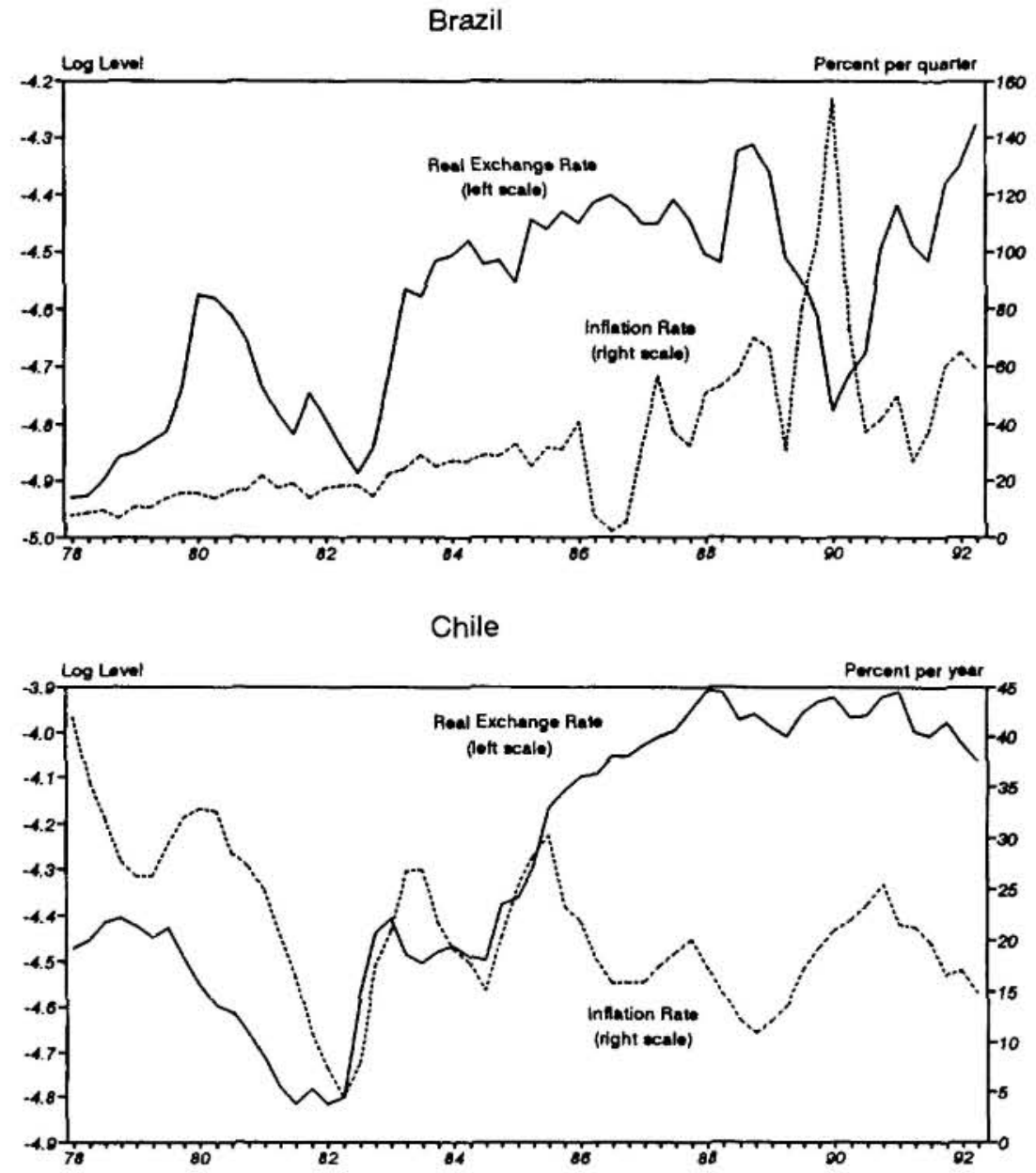

Colombia

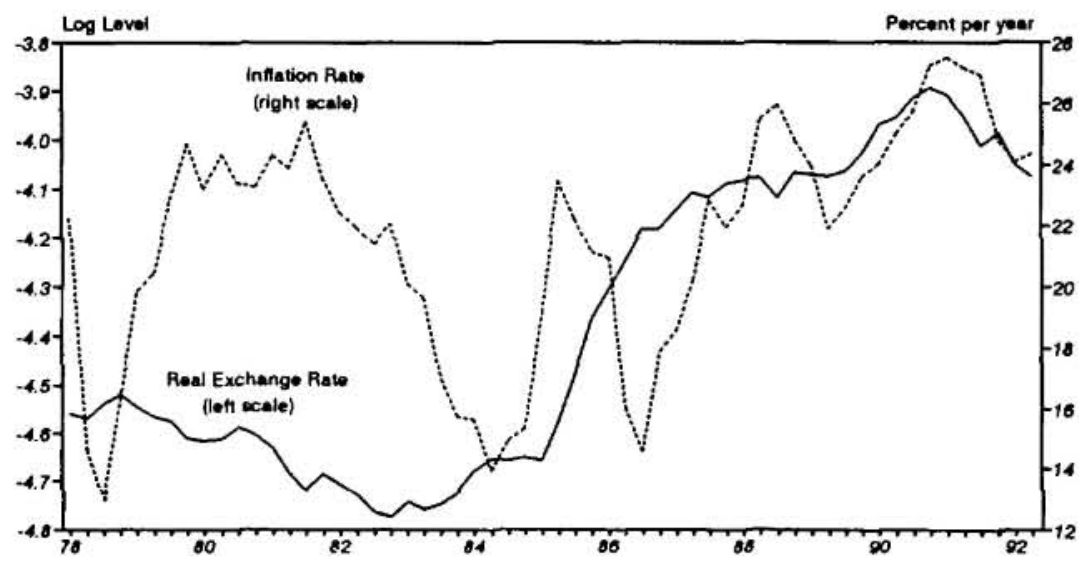

Source: IMF, International Financial Statistics and Fund staff estimates.

Note: A decrease in the real effective exchange rate index denotes an appreciation. Inflation is computed as the change in the CPI over the previous quarter for Brazil and over the previous four quarters for Chile and Colombia. 

targeting. 1/ First, what are the inflationary consequences of giving up a nominal anchor? Second, can money provide the needed nominal anchor if capital is less than perfectly mobile? In the context of a log-linear stochastic model, Adams and Gros (1986) argue that, in the presence of PPP rules, inflation tends to be whatever it was in the past, modified by shocks to prices during the current period (i.e., inflation follows a random-walk). The intuition is simply that the exchange rate fully accommodates all price shocks and, hence, has no long-run equilibrium value. Furthermore, they show that a sustained policy of sterilizing monetary inflows (which is possible under no capital mobility) is unfeasible, as it leads to either unstable current account or foreign assets.

More recently, Lizondo (1991, 1993) and Montiel and Ostry (1991, 1992) have reexamined the same two issues (among others) in terms of a common reduced-form, deterministic model. 2/ As shown in Lizondo (1991), real exchange rate targeting is also inflationary in this framework, but the mechanism is fundamentally different from that highlighted in Adams and Gros (1986). Specifically, the demand for non-traded goods depends positively on the real exchange rate (defined as the price of traded goods relative to non-traded goods) and real private wealth. Real private wealth, in turn, depends negatively on revenues from the inflation tax. Hence, equilibrium in the non-traded goods market requires that the steady-state inflation rate be that which generates, through its impact on inflation tax revenues, a level of real private wealth which is consistent with the targeted real exchange rate. $\underline{3}$ / Therefore, a more depreciated real exchange rate can only be achieved with higher inflation. 4/ with regard to whether money can provide the needed nominal anchor with imperfect capital mobility, Montiel and Ostry (1992) conclude that such a policy is not feasible in the long run as an ever widening spread in the parallel market would lead to a breakdown of the system.

This paper takes a new look at real exchange rate targeting, from both a theoretical and econometric point of view. Specifically, the purpose of the paper is two-fold. First, we go back to basics and analyze the two key questions mentioned above in the context of a simple, neo-classical, optimizing model. By so doing, we highlight mechanisms which are quite different from those emphasized by either Adams and Gros (1986) or Lizondo,

1/ Early work by Dornbusch (1982) focused on the effects of PPP rules on the trade-off between output and price-level variability. Many of the issues raised by Adams and Gros (1986) had already been discussed at length in the volume edited by Williamson (1981), mainly in the context of Latin America.

2/ The essential mechanism provided in Lizondo is retained in the other three papers.

3/ The elasticity of money demand is assumed to be below unity, so that higher inflation implies higher revenues from the inflation tax.

4/ Lizondo (1991) implicitly assumes that government expenditure on traded goods acts as the residual variable in that it accommodates the higher tax revenues. 
(1991, 1993), and Montiel and Ostry (1991, 1992). Second, we test the main implication of our model for Brazil, Chile, and Colombia. Furthermore, we also provide empirical evidence on the mechanism emphasized by Lizondo (1991, 1993) and Montiel and Ostry (1991, 1992).

The analysis is based on a simple representative-consumer, cash-inadvance model with flexible prices. We first show that, in the absence of fiscal policy, the steady-state real exchange rate is independent of (permanent) changes in the rate of devaluation. Hence, all that policymakers can hope to do is to target the real exchange rate for a limited period of time. Under perfect capital mobility, a more depreciated level of the real exchange rate--relative to its initial equilibrium value-can be achieved by generating higher inflation today than in the future. Intuitively, in a cash-in-advance model, the nominal interest rate affects the effective price of consumption because money is required to buy goods. Hence, if inflation, and thus the nominal interest rate, are expected to be lower in the future than today, consumption of traded goods falls today relative to the future. Since consumption of home goods cannot change (because output of home goods is constant), the exchange rate depreciates to accommodate the lower consumption of traded goods. Hence, targeting a more depreciated real exchange rate requires that inflation be higher today than in the future. In this sense, therefore, real exchange rate targeting is inflationary. Numerical simulations of the model suggest that, since the intertemporal elasticity of substitution for most developing countries is relatively low (see Reinhart and Vegh (1993)), the inflationary effects of real exchange rate targeting might be substantial.

The same results would obtain if one assumes that policymakers attempt to keep the real exchange rate constant in response to an external positive shock that would tend it to appreciate. Specifically, in the context of our model, suppose that the world nominal interest rate falls temporarily. In the absence of any policy response, such a shock reduces the effective price of consumption which leads to a current account deficit and a real exchange rate appreciation. Suppose now that, in the spirit of a PPP rule, the authorities' goal is to prevent the real exchange rate from appreciating. They can do that by keeping the domestic nominal interest rate constant; that is, by increasing the rate of devaluation (and thus the rate of inflation) by the same amount as the world nominal interest rate falls. Such a PPP-type of rule will therefore keep the real exchange rate constant but at the cost of higher inflation (relative to the equilibrium in which there is no policy response). Hence, in our model, either targeting a more depreciated real exchange rate or preventing the real exchange rate from appreciating in response to a positive external shocks is inflationary. 1/

1/ The welfare effects, however, differ. Targeting a more depreciated level is welfare reducing because there is no initial distortion. In contrast, keeping the real exchange rate constant is welfare improving because it offsets the distortion introduced by the temporary external shock. 
Under no capital mobility, we show that a temporarily more depreciated real exchange rate can be generated without inflation. However, the domestic real interest rate rises above its initial value, and keeps increasing for as long as the real exchange rate remains at its more depreciated level. Again, a numerical simulation of the model suggests that the rise in the domestic real interest rate may be substantial. Therefore, even if the absence of capital mobility enables policymakers to regain full control over inflation, the effects of real exchange rate targeting take the form of high real interest rates. In sum, given that in the real world neither perfect capital mobility nor perfect capital controls are likely to hold, the model suggests that real exchange rate targeting will lead to some combination of higher inflation and high domestic real interest rates.

Given that the analytical framework stresses the role of temporary shocks to the real exchange rate, the empirical section of the paper first assesses the relative importance of temporary shocks to the real exchange rate for Brazil, Chile, and Colombia. To this effect, we use Cochrane's (1988) methodology, which provides a measure of the persistence of shocks in a variable by examining the variance of its long differences. In all three countries considered, it is found that temporary shocks to the real exchange rate account for a sizable share of the variance of real exchange rate (between 43 and 62 percent). These results suggest that our emphasis on temporary shocks to the real exchange rate is well placed.

We then proceed to test, for the same three countries, the main implication of real exchange rate targeting under perfect capital mobility; namely, there should be a positive correlation between the temporary components of inflation and the real exchange rate. 1/ In order to test the above proposition, we decompose the real exchange rate, which is nonstationary in all three countries, into its permanent and temporary components using the Beveridge-Nelson decomposition. We then compute the correlation between the temporary component of the real exchange rate and inflation, as both of these variables are stationary. In all three cases, the correlation has the expected sign and is statistically different from zero, with values ranging from 0.26 to 0.42 . Hence, the evidence supports the temporary mechanism highlighted in the model.

Finally, we also provide some evidence on the long-run relationship between revenues from the inflation tax and the real exchange highlighted in Lizondo (1991, 1993) and Ostry and Montiel (1991, 1992). Our results suggest that there is room for an indirect link between inflation and the real exchange rate via wealth effects. However, the evidence is not conclusive, and further research is required which incorporates other determinants of the long-run equilibrium real exchange rate, such as government spending on non-traded goods.

1/ Note that in all the empirical work reported in this paper, a rise in the real exchange rate index denotes a depreciation. 
The paper proceeds as follows. Section 2 presents the theoretical analysis. Section 3 discusses the numerical simulations of the model. Section 4 contains the econometric work. Finally, Section 5 concludes.

\section{The Model}

Consider a small open economy inhabited by a large number of identical individuals blessed with perfect foresight. The representative consumer derives utility from the consumption of a traded good (whose price in terms of foreign currency is given and constant over time) and a non-traded (or home) good. Lifetime utility is given by

$$
\int_{0}^{\infty} u\left(c_{t}^{*}, c_{t}\right) \exp (-\beta t) d t
$$

where $c^{*}$ and $c$ denote consumption of traded and home goods, respectively, and $\beta(>0)$ is the subjective discount rate. The instantaneous utility function, $u($.$) , is twice-continuously differentiable (with positive partial$ derivatives), and strictly concave.

The country faces a constant world real interest rate, $r$. The domestic real interest rate (in terms of traded goods), $\rho$, may differ from the world real interest rate due to imperfect capital mobility. Let the domestic discount factor (in terms of traded goods) at $t, D_{t}$, be given by

$$
D_{t}=\exp \left(-\int_{0}^{t} \rho_{s} d s\right)
$$

Therefore, the representative consumer's lifetime budget constraint is given by (see Appendix) 1/

$$
\int_{0}^{\infty}\left(y_{t}^{*}+y_{t} / e_{t}^{+\tau} t\right) D_{t} d t=\int_{0}^{\infty}\left(c_{t}^{*}+c_{t} / e_{t}+i_{t} m_{t}\right) D_{t} d t
$$

where $\mathrm{y}^{*}$ and $\mathrm{y}$ denote the endowments of traded and home goods, respectively; e is the real exchange rate (i.e., the relative price of traded goods in terms of home goods); $\tau$ are real lump-sum transfers from the government; and $i$ denotes the instantaneous nominal interest rate (i.e., the real interest

1) To simplify notation and without loss of generality, we assume that, aside from endowment of future output, the individual and the country have no wealth as of time 0 . 
rate, $\rho$, plus the rate of devaluation) in terms of domestic currency. $1 /$ Equation (3) states that the present discounted value of consumption expenditure, $c / e+c^{*}$, and the rental cost of money, im, equals the present discounted value of disposable income, $y / e+y^{*}+\tau$, all evaluated in terms of traded goods, and employing the domestic discount factor, $D$.

Consumers must use money to purchase goods. Formally, they face a cash-in-advance constraint of the form

$$
\alpha\left(c_{t}^{*}+c_{t} / e_{t}\right) \leq m_{t}
$$

where $\alpha$ is a positive constant. Equation (4) requires the stock of real monetary balances not to fall short of total consumption expenditure, $\mathrm{c} / \mathrm{e}+$ $c^{*}$. Constraint (4) holds with equality at equilibrium if the rental cost of money (i.e., the nominal interest rate) is positive (the only case studied in the present paper). Therefore, budget constraint (3) can now be expressed as follows:

$$
\int_{0}^{\infty}\left(y_{t}^{*}+y_{t} / e_{t}+\tau_{t}\right) D_{t} d t=\int_{0}^{\infty}\left(c_{t}^{*}+c_{t} / e_{t}\right)\left(1+\alpha i_{t}\right) D_{t} d t
$$

The representative consumer's optimization problem consists of choosing the paths of $c$ and $c^{*}$ so as to maximize lifetime utility, equation (1), subject to the intertemporal budget constraint, equation (5), given the expected (equal to actual, due to perfect foresight) paths of $y, y^{*}, \tau, e$, $D$, and $i$. The first-order conditions for this problem are $2 /$

$$
u_{c}^{*}\left(c_{t}^{*}, c_{t}\right) \exp (-\beta t)=\bar{\lambda} D_{t}\left(1+\alpha i_{t}\right),
$$

1) The real exchange rate is defined as $e=E P^{*} / P$, where $E$ is the nominal exchange rate, in units of domestic currency per unit of foreign currency, $\mathrm{P}^{*}$ is the (constant) foreign currency price of traded goods, and $\mathrm{P}$ is the nominal price of home goods.

2/ To ensure the existence of a steady-state and eliminate inessential dynamics from the case of perfect capital mobility, it will be assumed that $\beta=r$. 


$$
\frac{u_{c^{*}}\left(c_{t}^{*}, c_{t}\right)}{u_{c}\left(c_{t}^{*}, c_{t}\right)}=e_{t},
$$

where $\bar{\lambda}$ is the (constant) Lagrange multiplier associated with budget constraint (5). Equation (6) indicates that the marginal utility of consumption of traded goods is proportional to the effective price of consumption, $1+\alpha i$. The effective price of consumption includes the opportunity cost of holding the real money balances needed to purchase goods. Equation (7) equates the marginal rate of substitution between traded and home goods to their relative price, e.

Assume, for simplicity, that endowments are constant over time; that is, $y_{t}-y$ and $y_{t}^{*}-y^{*}$ for all $t$. Hence, assuming away government consumption, the market equilibrium conditions for this economy are 1 /

$$
\begin{gathered}
c_{t}=y, \\
m_{t}=m_{t}^{s}, \\
\int_{0}^{\infty} c_{t}^{*} \exp (-r t) d t=\frac{y^{*}}{r}
\end{gathered}
$$

where $\mathrm{m}^{\mathrm{S}}$ denotes money supply. Equations (8) and (9) denote the equilibrium conditions for home goods and money, respectively. Since traded goods can be freely bought and sold in the rest of the world, equation (10) indicates that the country is only constrained to spend "within its budget;" namely, to make the present discounted value of its consumption of traded goods equal to the present discounted value of its endowment (where flows are discounted by the constant international interest rate $r$ ). 2/

For the sake of concreteness, we will focus on the case in which the exchange rate is exogenously determined by the monetary authority. A particular case would be a system of fixed exchange rates. In general, however, the exchange rate, although still a policy instrument, is allowed to vary over time. We will study two polar situations: (a) perfect

1/ For the sake of simplicity, no new notation is introduced to denote equilibrium values.

2/ See the Appendix for the derivation of equation (10). 
international capital mobility, and (b) no international capital mobility (i.e., perfect capital controls).

\section{Perfect capital mobility}

Under perfect capital mobility, the domestic real interest rate (in terms of tradables) equals the international one (i.e., $\rho=r$ ). Furthermore, the supply of money, $\mathrm{m}^{\mathrm{s}}$, is endogenous, implying that equilibrium condition (9) always holds. Therefore, under perfect capital mobility, equations (6), (7) and (8) are reduced to (recall that $\beta=r$ ):

$$
\begin{gathered}
u_{c^{*}}\left(c_{t}^{*}, y\right)=\bar{\lambda}\left(1+\alpha i_{t}\right), \\
\frac{u_{c}^{*}\left(c_{t}^{*}, y\right)}{u_{c}\left(c_{t}^{*}, y\right)}=e_{t} .
\end{gathered}
$$

Consider first steady-state solutions. By equation (12), a constant real exchange rate is obtained if, and only if, $c^{*}$ is constant over time; which, by equation (11), implies that the monetary authority must engineer a constant nominal interest rate. Since in this case $i_{t}-r+\epsilon_{t}$, where $\epsilon$ is the rate of devaluation, we have that a constant $i$ implies a constant rate of devaluation. In turn, by the overall budget constraint (10), a constant $c^{*}$ implies $c^{*}-y^{*}$, which is independent of the nominal interest rate, $i$, and, therefore, of the rate of devaluation, $\epsilon$. Hence, by (12),

$$
e_{t}=\frac{u_{c}\left(y^{*}, y\right)}{u_{c}\left(y^{*}, y\right)} .
$$

We have thus obtained the intuitively plausible implication that the steady-state real exchange rate is independent of (permanent changes in) the rate of devaluation. $1 /$ In other words, the real exchange rate will be

1/ This property does not hold in Lizondo (1991, 1992) and in Montiel and Ostry (1991, 1992), because in those models changes in the revenues from the inflation tax are not returned to the household in a lump-sum way, and thus affect private wealth. Hence, in these other models it is (implicitly) assumed that fiscal policy changes with inflation. 
given by (13) for any constant level of the rate of devaluation and thus of the nominal interest rate. Furthermore, since the utility function is assumed to be strictly concave, it can be verified that a constant- ${ }^{\star}$ path is a necessary and sufficient condition for a social optimum. Hence, in this economy it is socially optimal to have a constant rate of devaluation and. consequently, to generate the (unique) real exchange rate which can be kept constant over time. Any departure from this constant-real-exchangerate path will be non-optimal, which proves, for the case of perfect capital mobility, that any attempt to depreciate the real exchange rate by monetary policy (or, to be sure, by any other means) is bound to be socially costly. 1/

Suppose that the government attempts to depreciate the real exchange rate over and above the level achieved on the steady-state path. By previous considerations, such a policy can only attain its objective for a limited period of time (since we have shown that the steady state is unique). Since the utility function is strictly concave, it follows from equation (12) that e rises if, and only if, $c^{*}$ falls. By the resource constraint $(10)$, the latter requires $c^{*}$ to rise over its present steadystate leve1 sometime in the future.

For the sake of clarity, consider the case in which the government sets the real exchange rate at $\mathrm{e}^{1}$, exceeding its present steady-state level, from time 0 to time $T>0$ (referred to as the "first period") and, thereafter (referred to as the "second period"), the economy settles to its new steady state, indicated by $\mathrm{e}^{2}$ (see Figure 3 , Panel A). $\frac{2}{4}$ Thus, denoting the corresponding consumption of traded goods by $c^{\frac{2}{*} 1}$ and $c^{\star 2}$, we have, by equation (12), $c^{*} 1<y^{*} ;$ and, by the resource constraint $(10)$, $c^{* 1}<y^{*}<c^{* 2}$ (see Figure 3, Pane1 B). Hence, by equation (12), $\mathrm{e}^{2}$ is lower than initial e. Such a path of $c^{*}$ implies, using (11), that $i^{1}>i^{2}$ or, equivalently, that $\epsilon^{1}>\epsilon^{2}$ (see Figure 3, Panel C). 3 / Since within each period the relative price of traded goods in terms of home goods, e, is constant, it follows from the above analysis that the rate of inflation in period 1 exceeds that of period 2. Under perfect capital mobility, therefore, the model implies that in order to depreciate the real exchange rate over and above its current steady-state level, present inflation should be (and expected to be) higher now than in the future (i.e., inflation is higher in period 1 than in period 2).

1/ In more realistic examples, the real exchange rate associated with the social optimum may not be constant over time. However, one could prove in a wide variety of cases that any attempt to modify the real exchange rate via monetary policy (specifically, by variable-rate-of-devaluation policy) would result in an inferior social outcome.

2/ As discussed below, for the resource constraint (10) to hold, $e^{2}$ must be below its initial steady-state.

3/ Figure 3, Panel $\mathrm{C}$ assumes that the nominal interest increases with respect to its initial level (see the discussion below). 
Figure 3. Effects of Real Exchange Rate Targeting
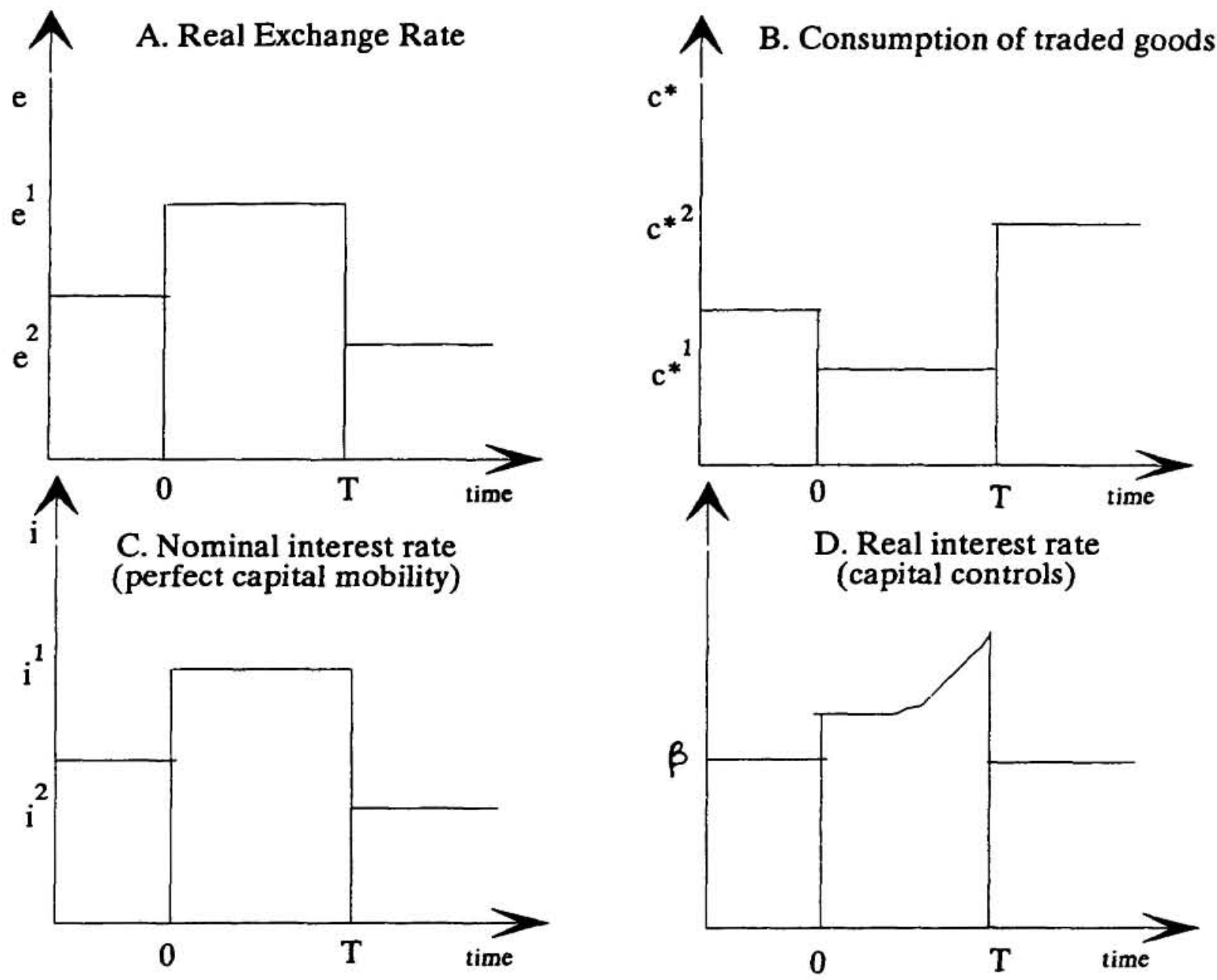

Notice that the above result is not tantamount to saying that the current rate of inflation has to increase relative to its past level. Rather, the result says that the policy must be such that the public expects inflation to fall over time. Here is where credibility issues come into play. For example, a present real exchange rate depreciation could be achieved with lower inflation today, if such action led the public to expect that inflation will continue falling in the future. However, in practice, this can only be achieved if the government engages in a credible adjustment that lowers the fiscal deficit. 1/ Hence, a present unsustainably low inflation will lead the public to expect higher, rather than lower, inflation in the future which, as argued above, would not be consistent with a real exchange rate depreciation today. Consequently, in the absence of a credible fiscal adjustment, a policy aimed at depreciating the real exchange rate is likely to jack up the rate of inflation (i.e., set present inflation higher than before).

Finally, note that the central result that real exchange rate targeting is inflationary would remain valid under a PPP-type of rule whereby the real exchange rate is kept constant in the face of external shocks. Specifically, consider an initial equilibrium in which foreign inflation is positive so that $i=i^{*}+\epsilon$, where $i^{*}=r+\pi^{*}$. Further, suppose that there is a temporary fall in foreign inflation and, thus, in the world nominal interest rate; that is, $i^{* 1}<i^{* 2}$. In the absence of any policy response, this positive external shock would lead to a temporary fall in the domestic nominal interest rate (i.e, $i^{1}<i^{2}$ ), which increases consumption of traded goods ( $i_{i} e, c^{* 1}>y^{*}>c^{* 2}$ ) and causes the real exchange rate to appreciate (i.e., $e^{1}$ falls below its initial leve1). The authorities can prevent this by setting $\epsilon^{1}$ higher than $\epsilon^{2}$ so as to exactly offset the changes in the world nominal interest rate. In other words, policymakers set $i^{1}\left(=i^{* 1}+\epsilon^{1}\right)$ equal to $i^{2}\left(=i^{* 2}+\epsilon^{2}\right)$. By so doing, consumption of traded goods and, thus, the real exchange rate remain unchanged with respect to the initial equilibrium (i.e., before the external shock hit). Hence, the policy is successful in preventing the real exchange rate from appreciating, but at the cost of higher inflation (i.e., $\epsilon^{1}>\epsilon^{2}$ ) relative to the situation in which the authorities would not have responded to the external shock. $2 /$

\section{No capital mobility}

Consider now the case in which capital controls are in place. It will be assumed that such controls can be perfectly enforced so that the stock of

1/ Naturally, this interpretation assumes that the inflation tax is used to finance in part a given level of government spending. As long as government spending does not change (i.e., as long as the fiscal adjustment involves only substituting the inflation tax for conventional taxes), the above model can be readily reinterpreted in this way since Ricardian equivalence holds.

2/ We are assuming, of course, that private sector expectations are not altered by the policy response itself. 
foreign assets in the hands of the public remains constant over time. 1 / It will be shown that, unlike the case of perfect capital mobility, a temporary real exchange rate depreciation can be obtained with zero inflation and a constant nominal exchange rate.

Unlike the case of perfect capital mobility, the domestic real interest rate (in terms of tradables), $\rho$, can transitorily differ from the international one. $\underline{2} /$ Once again, consider the experiment of setting $e_{t}=e^{1}$ for $0 \leq t<T$. Since, by assumption, the nominal exchange rate is fixed (i.e., $\epsilon=0$ ), $i=\rho . \underline{3}$ / Furthermore, equilibrium condition (10) still holds in this case, implying that $c^{*}{ }_{t}-c^{\star 1}<y^{*}$ during the first period. Thus, as before, if the economy settles down to a steady state after time $T$, we have $c^{*} t-c^{* 2}>y^{*}$, for $t \geq T$. 4 / Moreover, by equations (6) and (7), it is straightforward to show that in a steady state with fixed exchange rates $\mathbf{i}-\rho-\beta$. We will now show that, during the first period, the money supply can be manipulated in order to generate $\mathrm{e}=\mathrm{e}^{1}$ and $\mathrm{c}^{\star}=\mathrm{c}^{\star 1}$.

By first-order condition (6), it follows that

$$
\begin{array}{ll}
u_{c} *\left(c^{* 1}, y\right)=\lambda_{t}\left(1+\alpha i_{t}\right), & \text { for } 0 \leq t<T, \\
u_{c} *\left(c^{* 2}, y\right)=\lambda_{T}(1+\alpha \beta), & \text { for } t>T,
\end{array}
$$

where

$$
\begin{array}{cr}
\lambda_{t}=\bar{\lambda} D_{t} \exp (\beta t), & \text { for } 0 \leq t<T, \\
\lambda_{t}=\lambda_{T}, & \text { for } t \geq T .
\end{array}
$$

1/ Formally, the model becomes a dual exchange rates regime with no leakages; see, for instance, Obstfeld (1986) and, in the same cash-inadvance context, Guidotti and Végh (1992).

2/ If the system converges to a steady state, however, the domestic real interest rate converges to the subjective rate of discount $\beta$ which, by assumption, equals the international real interest rate (in terms of tradables), $r$.

3/ Recall that, by assumption, foreign inflation is zero.

4/ Notice that we can choose the same values of $c^{* 1}$ and $c^{* 2}$ as in the case of perfect capital mobility, because the economy as a whole faces the same overall budget constraint (10), independently of the degree of international capital mobility. 
Therefore, recalling equation (2) and that with fixed exchange rates $i=\rho$, we have

$$
\dot{\lambda}_{t}=\lambda_{t}\left(\beta-\dot{i}_{t}\right) \text {. }
$$

Thus, by equations (14) and (18), it follows that

$$
\dot{\lambda}_{t}=\left(\frac{1}{\alpha}+\beta\right) \lambda_{t}-\frac{u_{c}^{*}\left(c^{* 1}, y\right)}{\alpha}, \quad \text { for } 0 \leq t<T \text {. }
$$

By definition (recall equations (14) and (15)), $\lambda$ is continuous with respect to time. Moreover, from (15), it follows that $\lambda$ must attain a welldefined level at time T. Formally, then, the equilibrium solution is associated with the continuous path of $\lambda$ that satisfies dynamic equation (19) and terminal condition (15). We now have the basic elements to proceed with the substantive part of the analysis.

We first show that $\lambda$ decreases over time. Suppose, to the contrary, that $\lambda$ increases over time. This implies, from equation (19) that $(1 / \alpha+\beta) \lambda_{0}>u_{c *}\left(c^{* 1}, y\right) / \alpha$. Then, since $\lambda_{T}>\lambda_{0}$ and $c^{* 1}<c^{* 2}$, it follows, using (12), that $(1 / \alpha+\beta) \lambda_{\mathrm{T}}>\mathrm{u}_{\mathrm{c} *}\left(\mathrm{c}^{* 1}, \mathrm{y}\right) / \alpha>\mathrm{u}_{\mathrm{c} *}\left(\mathrm{c}^{* 2}, \mathrm{y}\right) / \alpha$, which contradicts terminal condition (15). Therefore, $(1 / \alpha+\beta) \lambda_{0}<u_{c *}\left(c^{* 1}, y\right) / \alpha$ which implies, by equation (19), that $\lambda$ decreases over time. $1 /$ Consequently, by equation (14), the nominal interest rate increases over time. Moreover, by equation (14) and the above finding that $(1 / \alpha+\beta) \lambda_{0}<$ $u_{c *}\left(c^{* 1}, y\right) / \alpha$, it follows that

$$
u_{c} *\left(c^{* 1}, y\right)=\lambda_{0}\left(1+\alpha i_{0}\right)>\lambda_{0}(1+\alpha \beta)
$$

implying that $i_{0}>\beta$. Therefore, if before the attempt to raise the real exchange rate the economy was in steady-state equilibrium, an overdepreciated real exchange rate can be sustained by a jump in the nominal/real interest rate, followed by further rises until the policy is

1/ Note that it cannot be the case that $(1 / \alpha+\beta) \lambda_{0}=u_{c *}\left(c^{* 1}, y\right) / \alpha$. If that were the case, $\lambda_{\mathrm{t}}=\lambda_{0}$ for $0 \leq \mathrm{t}<\mathrm{T}$, and terminal condition (15) would be violated. 
abandoned at time $T$ (and $i$ goes back to its steady-state level $\beta$ ), as illustrated in Figure 3, Panel D. $1 /$

In sum, the analysis has shown that, under no capital mobility, a temporary depreciation of the currency in real terms can be achieved without affecting the inflation rate if it is accompanied by a temporarily tight credit stance. As expected, tight credit is achieved by lowering real monetary balances. To prove it, notice that the cash-in-advance constraint (4) and equilibrium condition (8) imply

$$
m_{t}=c_{t}^{*}+\frac{y}{e_{t}}
$$

Hence, $m$ falls at time 0 because e rises and $c^{*}$ increases and remains constant in each of the periods. Consider the domestic credit policy that supports such a path of the money supply. At time 0 , domestic credit is reduced to engineer the drop in the money supply. Thereafter, and for the rest of the first period, the monetary authorities fully sterilize the reserve inflow that results from the current account surplus, so as to keep the money supply constant. At time $T$, domestic credit is increased to support the higher consumption of traded goods and lower real exchange rate.

The above result testifies to the much greater power that monetary policy has under imperfect capital mobility. In our example, the real exchange rate can be changed by manipulating the supply of money but, remarkably enough, without having to change the rate of inflation. It should be pointed out, however, that even in the extreme case of no international capital mobility, temporary changes in the real exchange rate are socially costly. Actually, our example dramatizes this point since the associated social costs of temporary changes in the real exchange rate are identical to those borne under perfect capital mobility. 2/

The power of monetary policy is undermined also in this case if government policy is not fully credible. Consider, for example, the case discussed above, in which the public expects high inflation in the future, irrespective of government announcements. Under those conditions, the expected future interest rate is largely independent of present announcements. Hence, in order to provoke a temporary depreciation of the real exchange rate, the government will be forced to increase current

1/ A PPP-type of rule would lead to similar results, as discussed above for the perfect capital mobility case. Hence, keeping the real exchange rate constant in the face of a temporary external shock that would tend to appreciate would entail high and rising real interest rates relative to the situation in which there is no policy response.

2/ This point should be obvious as the path of $c^{*}$ is the same in both cases. 
interest rates even further than it would under perfect credibility. In a more realistic model in which there is a positive stock of short-term government debt, higher interest rates would worsen the fiscal balance, possibly generating the high inflation expected by the public.

\section{Simulation of the Model}

The previous section presented a simple example in which the government is able to temporarily set the real exchange rate at a more depreciated level than in the steady-state by either raising inflation in the present relative to the future (under perfect capital mobility) or increasing real interest rates (under no capital mobility). This section discusses a numerical illustration of the model to get a sense of the orders of magnitudes involved. 1/ Specifically, we are interested in assessing how much inflation and real interest rates must rise to generate a given depreciation of the real exchange rate. $2 /$

For the purposes of simulating the model, we need to specify preferences. Assume that the instantaneous utility function exhibits constant relative risk aversion:

$$
u\left(c_{t}^{*}, c_{t}\right)=\frac{z_{t}^{1-\frac{1}{\eta}}-1}{1-\frac{1}{\eta}} \text {, }
$$

where $\eta(>0)$ is the intertemporal elasticity of substitution, and $z$, an index of total consumption takes the Cobb-Douglas functional form:

$$
z_{t}=c_{t}^{* q} c_{t}^{1-q} \text {, }
$$

where $q$ denotes the share of traded-goods consumption in total consumption. We now have all the elements needed to simulate the model under both perfect capital mobility and capital controls.

1) See Reinhart and Végh (1992) for a similar numerical exercise under perfect capital mobility aimed at assessing the quantitative importance of imperfect credibility in exchange rate-based stabilization programs.

2/ For the sake of concreteness, we will assume that the nominal interest rate does not change across steady-states and is equal to $r$ (i.e., steadystate inflation is zero). Hence, in the first period the nominal interest rate is higher than in the initial steady-state. 


\section{Perfect capital mobility}

Taking into account equations (22) and (23), first-order conditions (11) and (12) become:

$$
\begin{gathered}
q z_{t}^{-\frac{1}{\eta}}\left(\frac{y}{c_{t}^{*}}\right)^{1-q}=\bar{\lambda}\left(1+\alpha i_{t}\right), \\
\frac{q y}{(1-q) c_{t}^{*}}=e_{t} .
\end{gathered}
$$

Using (24), (25), and resource constraint (10), a closed-form solution for $c^{*}$ can be derived:

$$
c_{t}^{*}=y^{*} \frac{p_{t}^{-\eta^{*}}}{r \int_{0}^{\infty} p_{t}^{-\eta^{*}} \exp (-r t) d t}
$$

where

$$
\begin{gathered}
p_{t}=1+\alpha i_{t}, \\
\eta^{*}=\frac{\eta}{q+(1-q) \eta},
\end{gathered}
$$

To simplify notation, equation (27) defines the effective price of consumption, while equation (28) defines the intertemporal elasticity of substitution relevant for traded goods. 1/ Note that if $i$, and thus $p$,

1) It should be noted that, when $q=1$, equation (26) reduces to the closed-form solution that would hold in a one-good model (see Reinhart and Végh (1992)). Thus, this two-good setting makes clear that the intertemporal elasticity of substitution relevant for traded-goods consumption, $\eta^{*}$, may differ from the elasticity of substitution of aggregate consumption, $\eta$. Note that if $q=1$, then $\eta^{*}=\eta$. However, if $\eta<1$ (the relevant case in practice, see below), $\eta^{*}>\eta$. 
are constant over time, then the term that multiplies $\mathrm{y}^{*}$ on the right-hand side of equation (26) is unity, which implies that $c_{t}^{*}=y^{*}$ for all $t$. If $i$, and thus $\mathrm{p}$, vary over time, then $c^{*}$ will also vary over time. In this case, the parameter $\eta^{*}$ plays a key role in determining the response of $c^{*}$.

Specifically, if $p$ is higher in the present than in the future, then today's consumption of traded goods is lower than in the future. The higher is $\eta^{*}$, the smaller will be today's consumption relative to future consumption.

To make equation (26) operational, we need to make explicit the path of $i$ and thus $p$. Following the theoretical example, suppose that $i_{t}=i^{1}$ for $0 \leq t<T$ and $i_{t}=i^{2}$ for $t>T$, where $i^{1}>i^{2}$. Then, denoting by $p^{1}$ and $p^{2}$ the respective effective prices (i.e., $p^{1}=1+\alpha i^{1}$ and $p^{2}=1+\alpha i^{2}$, where $\left.\mathrm{p}^{1}>\mathrm{p}^{2}\right)$, equation (26) reduces to:

$$
c_{t}^{*}=y^{*}\left(1-\exp (-r T)+\left(\frac{p^{2}}{p^{I}}\right)^{-\eta^{*}} \exp (-r T)\right)^{-1} \text { for } 0 \leq t<T
$$

where $p$ and $\eta^{*}$ are defined in equations (27) and (28), respectively. (An analogous expression holds for $t \geq T$.)

Using equations (25), (27), (28) and (29), we can compute the nominal interest rate which is needed to generate a given depreciation of the exchange rate. 1/ Assuming that $i^{2}-r=0.03$, Table 1 shows the nominal interest rate (in monthly effective terms) which generates during period 1 a real depreciation of 5,10 , and 15 percent for different values of $\eta$ and $T$ (expressed in years). $2 / 3 /$ For example, if $\eta-0.4$ and $T=1 / 2$ (half a year), then the nominal interest rate needs to be 4.97 percent per month (or 79.0 percent per year) for the real exchange rate to depreciate by 5 percent.

Four observations follow from the figures reported in Table 1:

1/ Specifically, we take $i^{2}$ as given and vary $i^{1}$ so as to generate through equation (29) the value of $c^{* 1}$ that implies through equation (25) the desired depreciation of the real exchange rate.

2/ Note that $i$ is an interest rate which is capitalized instantaneously. Hence, if $i$ is 3 percent, the corresponding yearly effective rate is 3.05 percent and the monthly rate is 0.25 percent. In what follows, and unless otherwise noticed, all interest rates are in expressed in effective terms.

3/ The following parameter values were used: $\alpha=0.15, q=0.4$, $r=0.03$. Without loss of generality (since we are only concerned with percentage changes), $y^{*}$ and $e$ were normalized to one. The values of $\alpha$ and $q$ were chosen based on actual data. Specifically, the ratio of M1 to private consumption was 20.0 for Brazil in 1987, 10.7 for Chile in 1991, and 16.7 for Colombia in 1988 (data from IFS). The value of q, based on the average share of traded-goods consumption during the period 1978-1986, was 0.47 for Brazil and 0.32 for Colombia (see Reinhart and Ostry (1992)). 
a. The inflationary consequences of engineering a temporary depreciation of the real exchange rate are likely to be substantial. Even though these figures should be viewed as an upper bound--given that in practice capital mobility is less than perfect--the order of magnitude is large enough to suggest that the inflationary effects would still be large under less than perfect capital mobility.

b. The real exchange rate target has a substantial effect on the inflation upsurge. In other words, for a given value of the intertemporal elasticiy of substitution (say, 0.4), targeting a real depreciation of 15 percent during one year results in considerable more inflation (a nominal interest rate of 15.55 percent per month) than targeting a real depreciation of 5 percent (a nominal interest rate of 4.97 percent per month).

c. The intertemporal elasticity of substitution plays a key role. Since the mechanism through which the real exchange rate depreciation is effected is intertemporal consumption substitution, it is not surprising that the magnitude of this parameter critically affects the inflationary consequences of real exchange rate targeting. For instance, for $\mathrm{T}=1$ and a real exchange rate depreciation of 10 percent, the nominal interest rate varies from 23.78 to 6.83 percent per month as $\eta$ varies from 0.15 to 0.8 . As reported in Reinhart and Végh (1993), intertemporal elasticities of substitution in developing countries such as Argentina, Brazil, Chile, Israel, Mexico, and Uruguay are clustered around 0.20. I/ Hence, these low values of $\eta$ are likely to exacerbate the inflationary consequences of real exchange rate targeting.

d. The time period during which policymakers seek to maintain a more depreciated exchange rate level is relatively unimportant. As Table 1 shows, the values of the parameter $T$ make little difference to the inflationary effects. For instance, for a real depreciation of 5 percent and $\eta=0.15$, the nominal interest rate varies only from 10.57 to 11.10 percent per month as $\mathrm{T}$ varies from half a year to two years. Hence, what matters is not so much the time period during which the more depreciated real exchange rate is maintained, but rather the desired target level.

1/ Reinhart and Végh (1993) use for estimation purposes a monetary model very similar to the present cash-in-advance model, but which allows for variable velocity. Depending on the parameters of the money demand, estimates for $\eta 1$ ie in the range 0.18-0.19 for Argentina, 0.07-0.13 for Brazil, 0.24-0.80 for Chile, 0.16-0.22 for Israel, 0.11-0.19 for Mexico, and 0.04-0.17 for Uruguay. With the exception of Uruguay for some parameters of the money demand, all estimates are statistically significantly different from zero. In a real model, using panel data which includes Brazil and Colombia, Ostry and Reinhart (1992) estimate the intertemporal elasticity of substitution to be around 0.4 . 
Table 1. Nominal Interest Rate Needed to Generate a Given Depreciation (In percent per month)

\begin{tabular}{|c|c|c|c|c|}
\hline & \multirow{2}{*}{$\begin{array}{l}\text { Intertemporal } \\
\text { elasticity of } \\
\text { substitution }\end{array}$} & \multicolumn{3}{|c|}{ Depreciation of real exchange rate } \\
\hline & & 5 percent & 10 percent & 15 percent \\
\hline \multirow[t]{3}{*}{$T=0.5$} & 0.15 & 10.57 & 23.35 & 39.26 \\
\hline & 0.4 & 4.97 & 10.07 & 15.55 \\
\hline & 0.8 & 3.43 & 6.73 & 10.15 \\
\hline \multirow[t]{3}{*}{$T=1$} & 0.15 & 10.75 & 23.78 & 40.06 \\
\hline & 0.4 & 5.05 & 10.22 & 15.81 \\
\hline & 0.8 & 3.48 & 6.83 & 10.31 \\
\hline \multirow[t]{3}{*}{$T=2$} & 0.15 & 11.10 & 24.67 & 41.74 \\
\hline & 0.4 & 5.20 & 10.55 & 16.34 \\
\hline & 0.8 & 3.58 & 7.05 & 10.63 \\
\hline
\end{tabular}




\section{No capital mobility}

In spite of having intrinsic dynamics, the model with capital controls model is simple enough to lend itself to an easy numerical solution. Our objective is to compute the initial and final values of the real interest rate path (i.e., $\rho_{0}$ and $\rho_{\mathrm{T}^{-}}$), depicted in Figure 3 , Panel $\mathrm{D}$, that generates a temporarily depreciated real exchange rate. The values of $c^{* 1}$ and $c^{* 2}$ are the ones that follow from the perfect capital mobility case since, by construction, the policy under capital controls studied in Section 3 supports such a path.

Since no additional insights are derived from solving the mode1, we will only indicate how the model is solved without reporting the solution itself. The linear differential equation (19) can be solved to obtain $\lambda_{0}$ as a function of $\lambda_{\mathrm{T}}$ and $c^{* 1}$. Since we know both $\lambda_{\mathrm{T}}$ (which follows from equation (15) using equations (22) and (23)) and $c \star 2, \lambda_{0}$ can be computed. Given $\lambda_{0}$ and $c^{* 1}, 1_{0}\left(=\rho_{0}\right)$ can be computed from equation (14), using equations (22) and (23). The value of $i_{T^{-}}$can be computed in the same way by recalling that $\lambda$ is continuous at $\mathrm{t}-\mathrm{T}$.

The results of the simulation are reported in Table 2. Each entry reports two values of the real interest rate path depicted in Figure 3 , Panel D: the first is the value of the real interest rate at time 0 , while the second is the value at time $\mathrm{T}^{-}$(i.e, just before the real exchange rate falls). In general, the initial increase in real interest rates is rather small. 1/ However, the real interest eventually reaches high, and in some cases exorbitant, levels. Note that the final value taken by the real interest rate (or the nominal interest rate) coincides with the value that the nominal interest rate takes in the perfect capital mobility case, as a comparison of Tables 1 and 2 reveals. This should not come as a surprise since terminal condition (15) also holds under perfect capital mobility, which implies that $\lambda_{\mathrm{T}}=\bar{\lambda}$. Hence, since consumption is the same in both cases, $\rho_{\mathrm{T}^{-}}\left(=\mathrm{i}_{\mathrm{T}^{-}}\right.$) (under no capital mobility) equals $\mathrm{i}^{1}$ (under perfect capital mobility).

The same observations made for the case of perfect capital mobility apply here. In particular, the key parameters are the intertemporal elasticity of substitution and the target level of the real interest rate. The time frame during which the more depreciated real exchange rate is in effect plays a minor role.

In conclusion, it should be borne in mind that Tables 1 and 2 represent two extreme situations--perfect capital mobility and perfect capital immobility--neither of which is likely to hold in practice. In the real world, the applicable scenario will be somewhere in between, even when it

1/ The steady-state value of the real interest rate is 0.25 percent per month. In all the entries of Table 2, the value of the real interest rate at time 0 is higher than the steady-state value, although in some cases this is not evident from the table as figures have been rounded to two decimals. 
Table 2. Real Interest Rate Needed to Generate a Given Depreciation (In percent per month)

\begin{tabular}{|c|c|c|c|c|}
\hline & \multirow{2}{*}{$\begin{array}{l}\text { Intertemporal } \\
\text { elasticity of } \\
\text { substitution }\end{array}$} & \multicolumn{3}{|c|}{ Depreciation of real exchange rate } \\
\hline & & 5 percent & 10 percent & 15 percent \\
\hline \multirow[t]{3}{*}{$T=0.5$} & 0.15 & $0.55-10.57$ & $0.79-23.35$ & $0.99-39.26$ \\
\hline & 0.4 & $0.40-4.97$ & $0.53-10.07$ & $0.65-15.55$ \\
\hline & 0.8 & $0.35-3.43$ & $0.45-6.73$ & $0.53-10.15$ \\
\hline \multirow[t]{3}{*}{$T=1$} & 0.15 & $0.26-10.75$ & $0.27-23.78$ & $0.27-40.06$ \\
\hline & 0.4 & $0.26-5.05$ & $0.26-10.22$ & $0.26-15.81$ \\
\hline & 0.8 & $0.25-3.48$ & $0.26-6.83$ & $0.26-10.31$ \\
\hline \multirow[t]{3}{*}{$T=2$} & 0.15 & $0.25-11.10$ & $0.25-24.67$ & $0.25-41.74$ \\
\hline & 0.4 & $0.25-5.20$ & $0.25-10.55$ & $0.25-16.34$ \\
\hline & 0.8 & $0.25-3.58$ & $0.25-7.05$ & $0.25-10.63$ \\
\hline
\end{tabular}


has been moving towards the perfect capital mobility case during the last 20 years. Therefore, in practice, targeting a over-depreciated real exchange rate for a limited period of time is bound to result in both higher inflation and higher real interest rates. Under this interpretation, Tables 1 and 2 suggest upper bounds for the order of magnitudes involved.

\section{Empirical Implications}

The model outlined in Section 2 implies that the steady-state real exchange rate is independent of (permanent changes) in monetary policy. Hence, there is no direct steady-state link between inflation and the real exchange rate. $1 /$ Hence, the monetary authorities' impact on the real exchange rate is, at best, transitory. This section examines some of the main empirical implications of the theoretical framework. Given that the model emphasizes temporary changes in the real exchange rate, we first assess the relative importance of temporary shocks in explaining the total variability of the real exchange rate for Brazil, Chile, and Colombia. $2 /$ We then examine empirically the main implication of the model: if there is some measure of capital mobility, inflation will accelerate during episodes in which the real exchange rate is depreciated relative to its permanent, "steady-state" level. To this end, we compute the correlation between inflation and the "cyclical" component of the real exchange rate, as the latter captures transitory deviations from its steady-state level.

Quarterly data for the real exchange rate and consumer prices for the period January 1978 to December 1992 are employed. The empirical analysis that follows requires that the individual time series properties of the variables of interest be known beforehand. The results of the augmented Dickey-Fuller (ADF) and Phillips-Perron (P-P) tests, which are reported in Table 3, indicate that the real exchange rate and the price level have one unit root (i.e., they are difference stationary). Therefore, inflation is a stationary variable. $3 /$ The unit root tests, however, do not provide information on the relative importance of the permanent component.

\section{Temporary shocks to the real exchange rate}

To determine how important a role temporary shocks play in explaining real exchange rate variability, we employ Cochrane's (1988) methodology, which provides a measure of the persistence of shocks to a variable by examining the variance of its long differences. Specifically, if the variable $x$ has the following representation,

1/ In other models, there exists a steady-state relationship between inflation and the real exchange rate (see below).

2/ Of course, other policy actions not discussed in this paper, such as changes in government spending on nontraded goods will have permanent effects on the real exchange rate (see for example, Edwards (1989)).

3/ When the test results give conflicting results (for instance, inflation in Colombia), a higher weight is attached to the P-P tests, which allow for more general forms of heteroskedasticity. 
Table 3. The Unit Root Tests

1979: II - 1992: II

Regression: $\Delta y_{t}=\mu+\beta t+\alpha y_{t-1}+\sum_{i=1}^{k} \delta \Delta y_{t-i}+e_{t}$

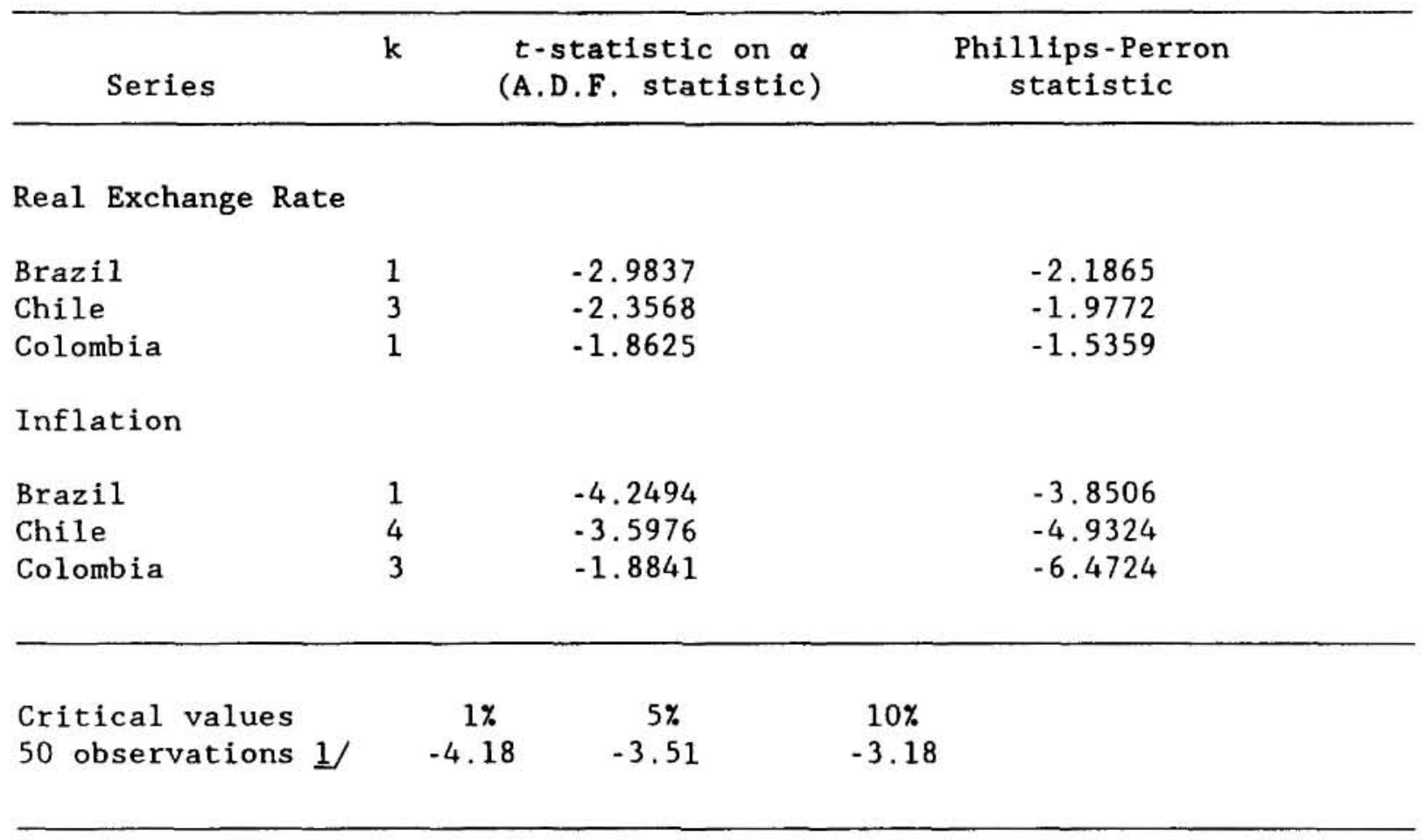

1/ The critical values are taken from Guilkey and Schmidt (1989).

Notes: The real exchange rate is in logs while inflation is measured as the first difference of the $\log$ of the price level. The actual number of observations is 52 . 


$$
\mathrm{x}_{t}=\delta \mathrm{x}_{t-1}+\epsilon_{t}, \quad \text { where } \epsilon_{t} \sim N\left(0, \sigma_{\epsilon}^{2}\right)
$$

then if $\delta=1, x$ follows a pure random walk and the variance of its $k$ differences grows linearly with the difference

$$
\operatorname{var}\left(\mathrm{x}_{t}-\mathrm{x}_{t-k}\right)=\mathrm{oo}^{2}{ }_{\epsilon} \text {. }
$$

If $\delta<1$ and $x$ is a stationary process, the variance of its $k$-differences is given by

$$
\operatorname{var}\left(x_{t}-x_{t-k}\right)=\sigma_{\epsilon}^{2}\left(1-\delta^{2 k}\right) /\left(1-\delta^{2}\right)
$$

Therefore, the ratio $(1 / k) \operatorname{var}\left(x_{t}-x_{t-k}\right) / \operatorname{var}\left(x_{t}-x_{t-1}\right)$ is equal to one if $x$ follows a random walk process and converges to zero if $x$ is stationary. If $\mathrm{x}$ has both permanent (random walk) and temporary (stationary) components, the ratio will converge to the ratio of the variance of the permanent shock to the total variance of $\mathrm{x}$. Thus, the closer that ratio is to unity, the lower is the relative importance of temporary shocks.

Table 4 summarizes the main results. The values of $k$ range between one and ten years. In all three countries considered, temporary shocks account for a sizable share of the variance of the real exchange rate. Temporary shocks are most important for Chile ( 62 percent of the variance) and least important ( 43 percent of the variance). for Brazil. Colombia falls in the middle of the range with temporary shocks accounting for about 54 percent of the variance of the real exchange rate.

On balance, these results would seem to indicate that, for these countries, temporary shocks play an important role in the behavior of real exchange rates. Hence, at least in this respect, the theoretical framework outlined in sections 2 and 3 is not devoid of empirical content. Our results contrast with those of Edwards (1989), who tentatively concludes temporary shocks play a relatively small role in determining the behavior of real exchange rates.

Edwards' (1989) conclusion is based on the results of a regression which has the level of the real exchange rate as the dependent variable, and includes as explanatory variables both permanent and temporary components of the terms of trade, government spending, and other "real" variables (see Edwards (1989)). The main problem with that approach is that not all variables appearing in the regression are integrated of the same order, which will bias the results towards finding no role for temporary shocks. Note that both the real exchange rate and, by construction, the "permanent 
Table 4. 1/k Times the Variance of $k$-differences of the Real Exchange Rate

\begin{tabular}{|c|c|c|c|c|}
\hline \multicolumn{5}{|c|}{$\sigma_{\mathrm{k}}{ }^{2} / \sigma_{1}{ }^{2}$ for various $\mathrm{k}$ (Quarters) } \\
\hline 8 & 16 & 24 & 32 & 40 \\
\hline \multicolumn{5}{|c|}{ Brazil } \\
\hline $\begin{array}{c}1.07 \\
(0.015)\end{array}$ & $\begin{array}{c}0.64 \\
(0.021)\end{array}$ & $\begin{array}{c}0.75 \\
(0.028)\end{array}$ & $\begin{array}{c}0.47 \\
(0.030)\end{array}$ & \\
\hline \multicolumn{5}{|c|}{ Chile } \\
\hline $\begin{array}{c}1.041 \\
(0.017)\end{array}$ & $\begin{array}{c}0.863 \\
(0.027)\end{array}$ & $\begin{array}{c}0.704 \\
(0.031)\end{array}$ & $\begin{array}{c}0.513 \\
(0.031)\end{array}$ & $\begin{array}{c}0.376 \\
(0.012)\end{array}$ \\
\hline \multicolumn{5}{|c|}{ Colombia } \\
\hline $\begin{array}{c}1.494 \\
(0.017)\end{array}$ & $\begin{array}{c}1.217 \\
(0.027)\end{array}$ & $\begin{array}{c}0.953 \\
(0.031)\end{array}$ & $\begin{array}{c}0.687 \\
(0.031)\end{array}$ & $\begin{array}{c}0.465 \\
(0.012)\end{array}$ \\
\hline
\end{tabular}

1/ Quarterly data was used. The real exchange rate indices are from the Information Notice System, IMF. Standard errors are in parentheses. The standard errors were tabulated from Monte Carlo simulations ( 600 replications) for $n-62$ and $k-32$ and 40 , under the null hypothesis of a random walk. 
component" of all the explanatory variables are non-stationary. 1 / However, also by construction, the "temporary component" of all explanatory variables is stationary. Hence, regression methods, such as OLS, will attach zero coefficients to all the stationary variables appearing in the right hand side, since asymptotically there can be no relationship between a nonstationary and stationary variable. However, such lack of statistical significance of the temporary components was taken as evidence that temporary shocks were not an important factor in real exchange rate behavior.

The methodology outlined here is more direct and does not require any estimation. However, it is important to note that this methodology does not discriminate among "types" of temporary shocks. It does not distinguish between a "temporary policy shock", such as the one considered in the previous exercise, from say, a temporary terms-of-trade shock, which underlies Edwards's (1989) exercise.

\section{Inflation and the real exchange rate}

The theoretical model suggests that inflation will accelerate when the authorities attempt to depreciate the real exchange rate beyond its equilibrium level. To examine this proposition we follow a two-step approach. First, employing the Beveridge-Nelson technique (Beveridge and Nelson (1981)) as modified by Miller (1988), we decompose the exchange rate into its "permanent" (or steady-state) component and "temporary" (or cyclical component). As discussed above, the identifying criteria for this technique is that the former captures the nonstationary component of the variable, while the latter captures its stationary element. Table A.1, in the Appendix, provides details about the ARMA processes that best described the real exchange rate for the three countries in our sample, while Appendix A.2 discusses the links between the "economic fundamentals" and the trend and cycle. Second, we examine the pairwise correlations between the cyclical component of the real exchange rate and inflation (which was also shown to be a stationary variable).

The inverse of the IMF index of the real exchange rate is used; hence, as in the theoretical model, an increase in the index denotes a real depreciation. When the cyclical component is negative, the actual exchange rate is "overvalued" relative to its equilibrium steady-state level. Hence, the model suggests that we should observe a positive correlation between inflation and the cyclical or temporary component of the real exchange rate. The corresponding correlations and their standard errors are reported in Table 5. In all three cases considered, the correlation has the anticipated sign and is significant at the 10 percent confidence level or higher. In all cases, the correlation is relatively low ( 0.26 to 0.42 range), suggesting that there are also important differences in the driving forces behind these two variables. This low correlation is evident from Figure 4, which plots inflation and the cyclical component of the real exchange rate.

\footnotetext{
1/ The Beveridge-Nelson (1981) trend-cycle decomposition was used.
} 
Figure 4. Temporary Component of Real Exchange Rate and Inflation

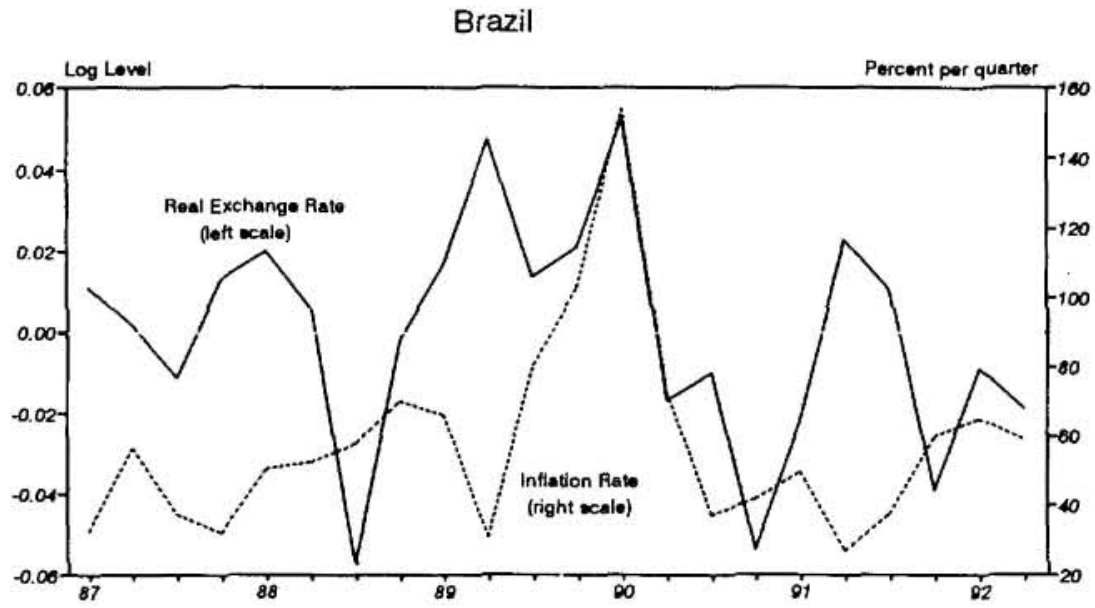

Chile

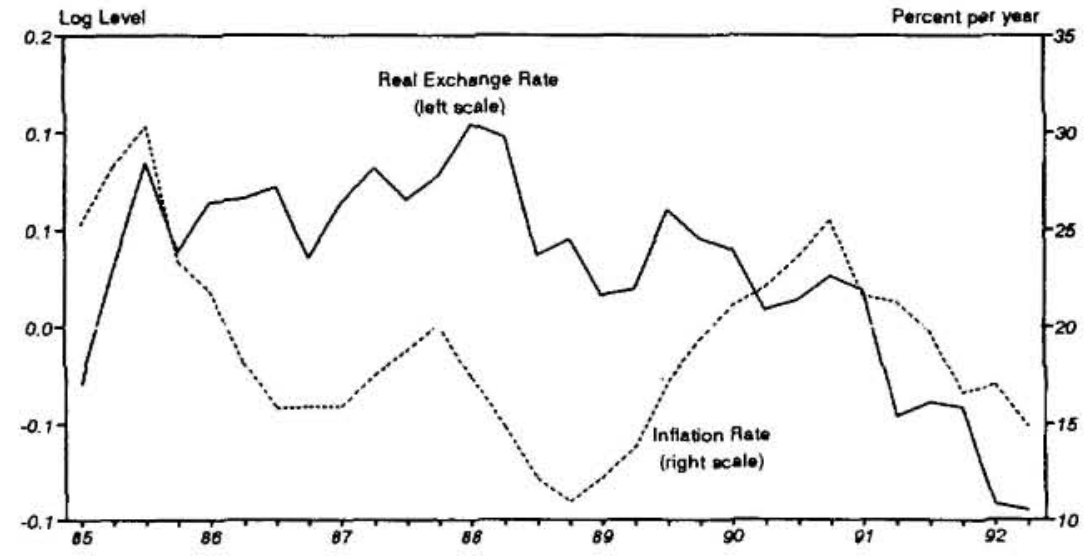

Colombia

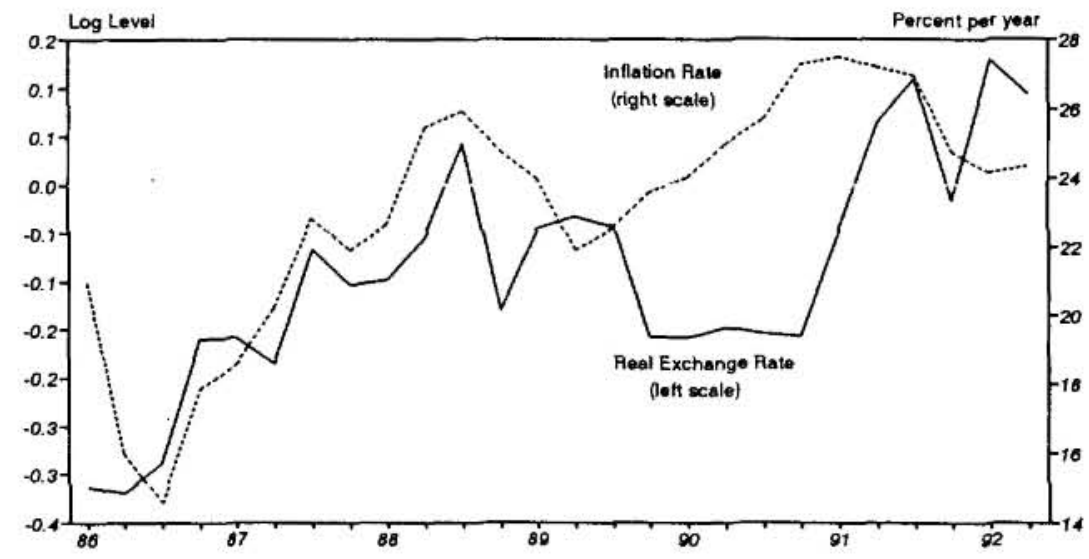

Source: IMF, International Financial Statistics and Fund staff estimates.

Note: A decrease in the real effective exchange rate index denotes an appreciation. Inflation is computed as the change in the CPI over the previous quarter for Brazil and over the previous four quarters for Chile and Colombia. 

Table 5. Pairwise Correlations $1 /$

1979: IV-1992:2

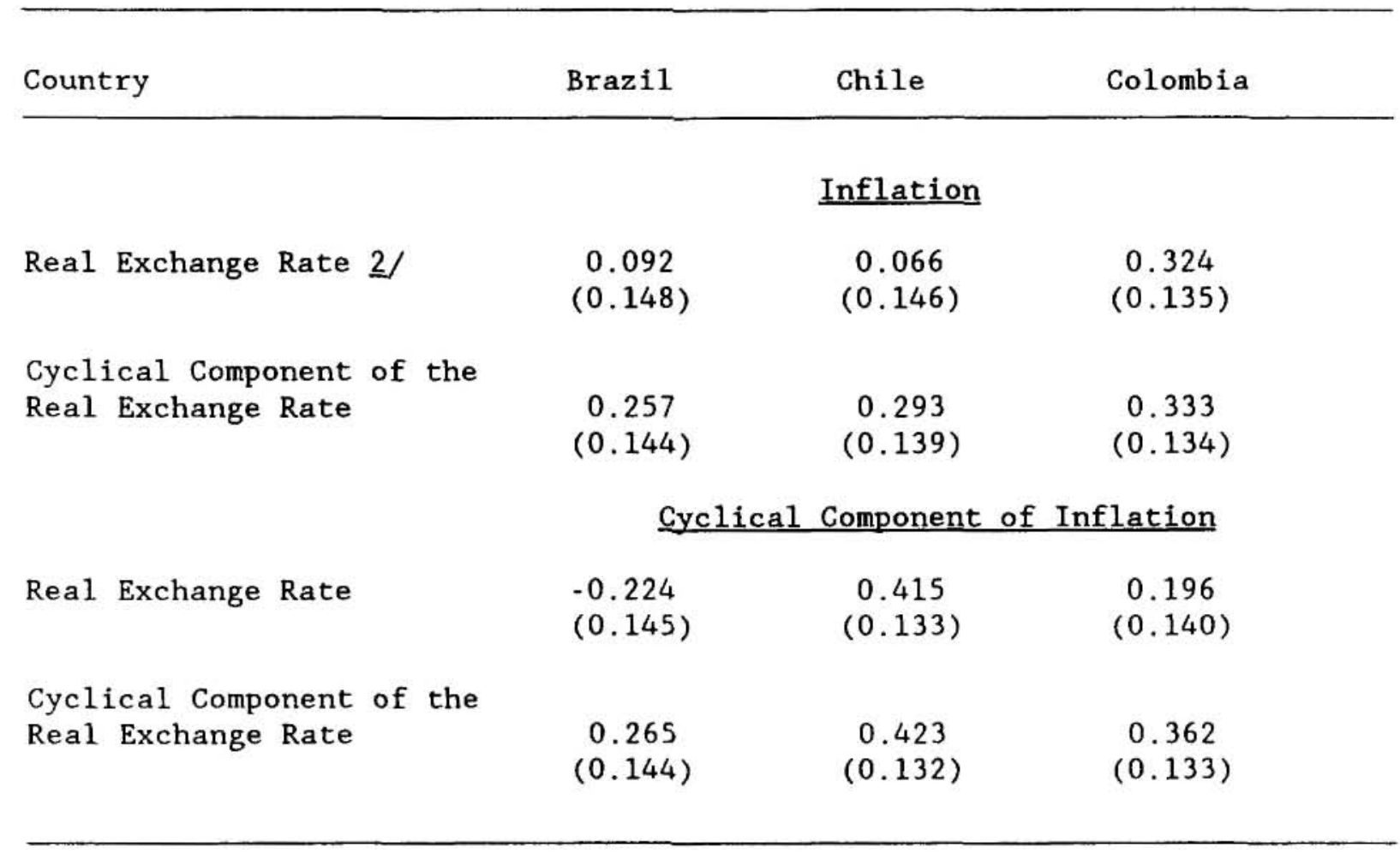

1/ Standard errors of the correlation coefficients are in parentheses.

2/ The correlations with the real exchange rate are only meant to be illustrative. Inference-making cannot proceed as usual given that the real exchange rate is $I(1)$ and inflation is $I(0)$. Such problems do not arise with the correlations involving the cyclical component of the real exchange rate, which by construction is $I(0)$.

Notes: The real exchange rate is in logs while inflation is measured as the first difference of the log of the price level. The trend-cycle decomposition of the real exchange rate was obtained using the BeveridgeNelson technique. The ARMA processes that model the change in the permanent component are presented in Table A.I in the Appendix. Since inflation was found to be stationary around a deterministic trend, the bottom panel of the this table reports the correlations for the cyclical deviations from trend. 
By contrast, no systematic relationship is evident from the correlations of the ( $\mathrm{log}$ ) level of the real exchange rate and inflation in two of the three countries (see Table 5). 1/ This lack of a systematic relationship between inflation and the real exchange rate has fueled the observation that Chile represents a case of successful real exchange rate targeting, in the sense that a policy of targeting the real exchange rate coexisted with declining inflation rates (see Edwards (1991)). The above results would suggest, however, that the lack of inflationary pressures in the case of Chile possibly stemmed from having a real exchange rate target that was, in effect, closely tracking the equilibrium real exchange rate. However, as in Brazil and Colombia, the evidence suggests that in periods when the real exchange rate was depreciated relative to its steady-state level inflation did tend to accelerate. 2 /

In sum, the empirical exercises summarized in this section yield two main observations, both of which are consistent with the theoretical model: (i) temporary shocks play an important role in explaining real exchange rate behavior, and (ii) there appears to be a systematic relationship between real exchange rate disequilibria and inflation.

\section{Implications of other models}

The theoretical model outlined in this paper has stressed the relationship between the temporary or cyclical component of the real exchange rate and inflation. However, other models (see Lizondo (1991, 1993) and Montiel and Ostry $(1991,1992)$ ) have focused on the relationship between inflation and the "permanent" or steady-state real exchange rate. Specifically, the relationship between these two variables implied by these models is an indirect one (in the sense that there is an implied relationship between revenues from the inflation tax, rather than inflation, and the real exchange rate), and comes through from wealth effects. 3/ In these models, the steady-state real exchange rate is determined by market clearing in the nontraded good sector. Demand for the nontraded good depends on its relative price (i.e. the real exchange rate), and wealth, which, in turn, depends on the inflation tax. Changes in the inflation tax affect household wealth because it is assumed that the government does not return revenues from the inflation tax to the household via a lump-sum transfer. Rather, the government uses these revenues to either increase spending on traded goods or accumulate international reserves. Hence, these models predict that the steady-state real exchange rate can be depreciated

1/ This is not surprising, since the two variables have different orders of integration any relationship is bound to be spurious.

2/ See Herrera (1991) and Carrasquilla (1992), who note for the case of Colombia that periods of real exchange rate disequilibria (in the sense of an overdepreciated real exchange rate) were characterized by inflationary pressures.

3/ As discussed above, for the countries in our sample, inflation is stationary while the real exchange rate is not. Hence, no direct steadystate relationship can exist between these two variables. 
by permanently increasing the inflation rate. 1/ An increase in inflation reduces households' wealth and decreases their demand for the nontraded good. As a result, the real exchange rate must depreciate to restore equilibrium in the market for home goods.

The empirical examination of a steady-state relationship between inflation and the real exchange rate is far from trivial because, in principle, there are a host of other variables (terms of trade, government spending, etc) that affect the steady-state real exchange rate, and which should be incorporated into the empirical analysis. At the very least, however, and given that we have in mind the equilibrium in the home goods market, the supply of home goods must be taken into account. Hence, to explore some of the empirical implications of these models we proceed in two steps. First, we establish the time series properties of the inflation tax and GDP (the latter will serve as a proxy for output of the nontraded good). As is well known, a steady-state relationship can only exist among variables which are integrated of the same order. Hence, the inflation tax and real GDP must be difference stationary (same as the real exchange rate) if the steady state relationship postulated by these models is to have empirical content. Second, for the cases where the all the variables are integrated of the same order, we proceed to examine via cointegration tests if a steady-state relationship among them can be identified.

Applying the same battery of tests as before, in all three countries considered, GDP per capita and the inflation tax (also on a per capita basis) were found to be nonstationary (however, the inflation tax as a percent of GDP is stationary). 2/ Hence, based on the individual unit root tests there is no a priori basis for ruling out the steady-state relationship postulated by Lizondo $(1991,1993)$ and Montiel and Ostry (1991, 1992).

To examine whether output and the inflation tax are sufficient to pin down the steady-state behavior of the real exchange rate we performed the cointegration tests of Johansen $(1988,1990)$. The results summarized in Table 6 report the $\lambda-\max$ and trace statistics, as well as their respective critical values. In addition, the estimated parameters for the cointegrating vectors (if these exist) are also reported at the bottom of the table. Cointegration among the real exchange rate, real GDP per capita (a proxy for output of nontraded goods), and the inflation tax per capita was only detected for Colombia. If the assumption of a single traded good is relaxed, and a distinction is made between importables and exportables, the equilibrium real exchange rate also depends on the terms of trade (see for example, Edwards (1989)). Including the terms of trade in the vector of variables was particularly important for Chile. Once the terms of trade are included, cointegration obtains (see Table 6 and critical values for $n=4$ ). Hence any meaningful inference will be limited to those two cases.

1) It is assumed that real money demand is inelastic, so that an increase

in inflation raises revenues from the inflation tax.

2/ These results are not reported but are available upon request. 
Table 6. Cointegration Tests for the Real Exchange Rate, the Inflation Tax, and Real GDP $1 /$

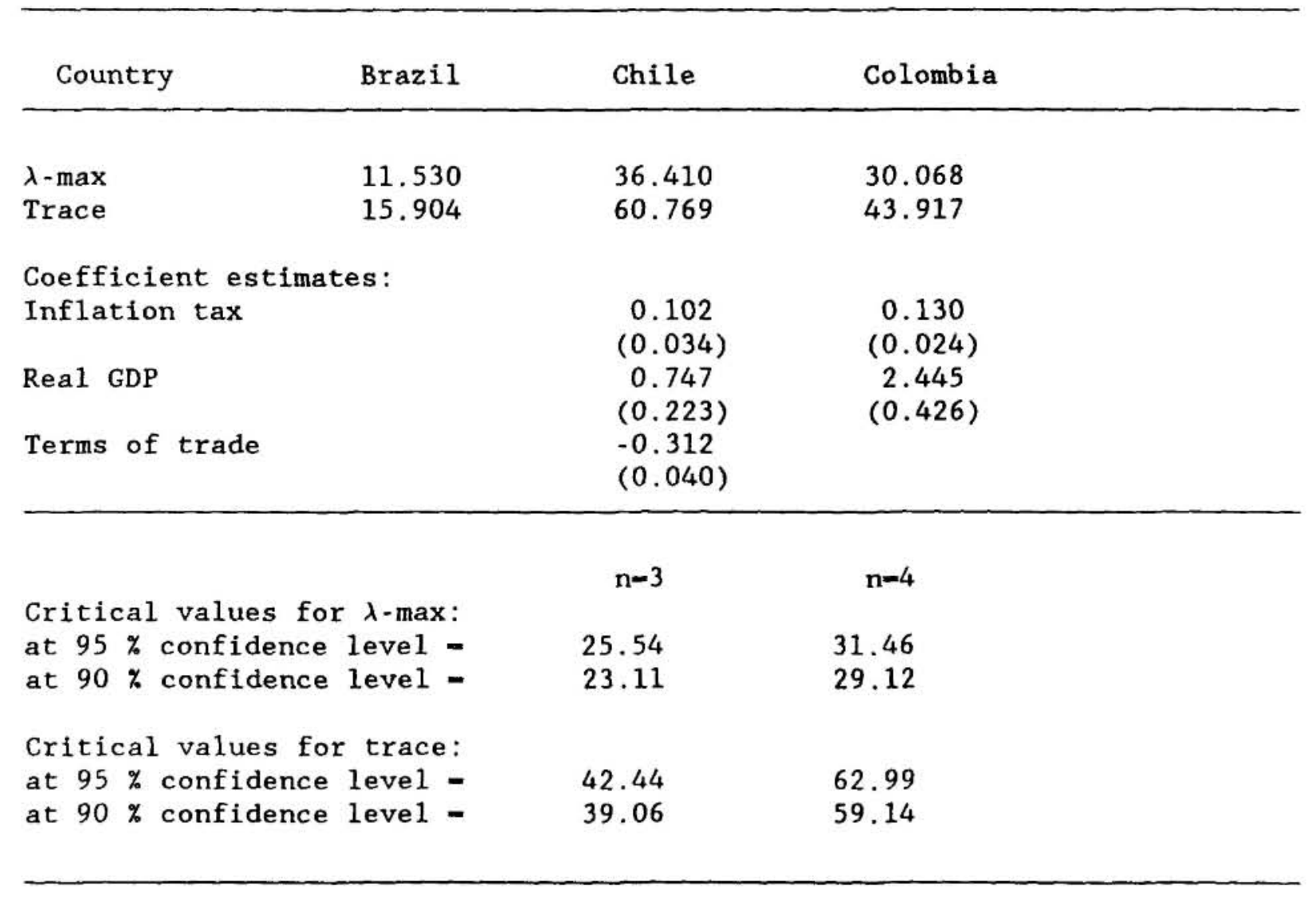

\section{1/ Coefficients are only reported when cointegration obtains.}

Notes: Standard errors are in parentheses. The number of lags in the vector autoregression is three. The critical values are those under the null of no cointegration. The source of the critical values is osterwaldLenum (1992). For the specification that includes the terms of trade, the $\lambda-\max$ and trace statistics for Brazil are 25.08 and 50.44 , respectively. 
The Stock-Watson (1991) estimates of coefficients of the cointegrating vectors, which deal with the biases introduced in the cointegrating regressions by simultaneity and serial correlation in the errors, indicate that the variables enter significantly and with the anticipated signs. Hence, an expansion in output depreciates the real exchange rate, implying a positive coefficient; similarly, an increase in the inflation tax depreciates the equilibrium real exchange rate. An improvement in the terms of trade, other things equal, tends to appreciate the equilibrium real exchange rate (a negative coefficient). For the case of Brazil, little inference is possible as cointegration did not obtain. 1/ The persistent lack of cointegration for Brazil is likely indicative of a misspecification problem, possibly due to omitted variables or perhaps to the linearity imposed in the cointegration tests. The relationship among the real exchange rate and the explanatory variables indicated by these models may simply be nonlinear. As suggested in Lizondo (1991), a leading candidate in this list of potential omissions is public expenditure on nontraded goods. 2/

Our results tend to suggest that there is potential for quantitatively important indirect links between inflation and the equilibrium real exchange rate. However, the evidence is not conclusive, which suggests that a more comprehensive model of equilibrium real exchange rate determination may be needed to be able to quantify the relationship between the real exchange rate and the inflation tax.

\section{v. Final remarks}

Policies of targeting the real exchange rate are of ten pursued by developing countries that are trying to either maintain or enhance their international competitiveness. A simple optimizing model offers sharp predictions about the feasibility and macroeconomic consequences of such a policy. First, this framework suggests that the monetary authorities can only have a transitory impact on the real exchange rate; thus the model stresses the role of "temporary policy shocks", which have been largely ignored in the literature on the subject. Second, when there is perfect capital mobility, a policy that aims at depreciating the real exchange rate results in a temporarily higher inflation rate; when there is no capital mobility, the impact of the policy rule is reflected in higher real interest rates. Since neither extreme adequately depicts reality, the implication to be drawn is that an attempt to depreciate the real exchange rate beyond its equilibrium level is likely to be accompanied by both higher inflation and rising real interest rates.

1/ Indeed, the variables appear with the anticipated signs, but since these parameter estimates are neither unbiased nor consistent no conclusions are possible.

2/ See Roldos (1990) for some empirical evidence on the effects of government spending and other exogenous variables on the real exchange rate. 
Simulations of the model based on available parameter estimates were used to quantify the suggested tradeoff between international competitiveness and inflation and/or higher real interest rates. These exercises revealed that this tradeoff is likely to be steep. For instance, an attempt by the monetary authorities to push the real exchange rate 10 percent beyond its equilibrium level may require an inflation rate of about 10 percent per month. Moreover, the lower the degree of intertemporal substitution, the steeper the tradeoff. Since the empirical evidence suggests intertemporal elasticities of substitution in developing countries are relatively low, the tradeoff between a more depreciated real exchange rate and higher inflation is likely to be substantial.

This paper also attempts to fill a gap in the literature on real exchange rate targeting by providing empirical evidence of some of the key implications of the existing models. Three main stylized facts emerge from the experiences of Brazil, Chile and Colombia: first, temporary shocks, including (but not necessarily limited to) the type of policy shock outlined in the theoretical framework play an important role in determining real exchange rate behavior; second, partial correlations between the inflation rate and the cyclical or temporary component of the real exchange rate indicate that as suggested by the mode1, inflation increases when the real exchange rate is depreciated relative to its steady-state level; third, our results suggest that there is room for an indirect link between inflation and the real exchange rate via wealth effects. However, the evidence for the latter is not conclusive, and further research is required which incorporates other determinants of the long-run equilibrium real exchange rate, such as government spending on non-traded goods.

Since our empirical conclusions are based on the experience of three countries that have had one or more episodes of policies aimed at targeting the real exchange rate, a fruitful line for future research would broaden the coverage to include a more diverse group of countries that have had similar policies in place. Only by studying a more comprehensive sample of countries are the main empirical regularities associated with real exchange rate targeting likely to emerge. In addition, this paper has focused almost exclusively on the direct and indirect links between inflation and real exchange rate targeting. A more comprehensive evaluation of macroeconomic consequences of these policies would also have to examine the behavior of other key variables, such as exports, the current account, and growth. 
APPENDIX I

\section{Derivation of some expressions in the text}

Under capital controls (modeled as a dual exchange rates regime), the consumer's flow constraint is given by (see, for instance, Guidotti and Végh (1992)):

$$
\dot{a}_{t}=\frac{y_{t}}{e_{t}}+y_{t}^{*}-\frac{c_{t}}{e_{t}}-c_{t}^{*}+\rho_{t} q_{t} b_{t}-\epsilon_{t} m_{t}+\tau_{t}
$$

where $b$ is the real net stock of bonds; $q$ is the domestic price of real bonds; $a(-m+q b)$ denotes real financial assets; and $\tau$ are real transfers from

the government. Multiplying equation (33) by $D_{t}$, integrating forward, and imposing the standard transversality condition, equation ( 3 ) in the text follows (note that $i=\rho+\epsilon$ ).

In order to derive the resource constraint (10), consider the government's flow constraint:

$$
h_{t}=\dot{m}_{t}+\epsilon t_{t}+r h_{t}-\tau_{t},
$$

where $h$ denotes the government's net stock of bonds. Combining (33) and (34), it follows that

$$
\dot{h}_{t}+q_{t} \dot{b}_{t}=y_{t}^{*}-c_{t}^{*}+r\left(h_{t}+b_{t}\right)
$$

Under perfect capital mobility, $q=1$; under capital controls, $b_{t}=b_{0}$ for all $t$ so that $\dot{\mathrm{b}}_{t}=0$. In either case, integrating equation (3) forward and imposing the appropriate transversality condition yields equation (10), where $\mathrm{k}_{0}=0$.

\section{Trend-cycle decomposition and the "economic fundamentals"}

The Beveridge-Nelson approach to decomposing a time series into its permanent and cyclical components relies exclusively on the univariate behavior of the series in question and, hence, it is silent as to how trend and cycle interact with other economic variables. The purpose of this appendix is to briefly examine whether the constructed trends and cycles of the real exchange rate are linked to economic fundamentals. We focus on the cycle and subsequently consider the behavior of the "equilibrium" permanent component.

As noted in the text, the cyclical component of the real exchange rate is correlated with inflation in a way predicted by theory. In addition, the 


\section{APPENDIX I}

constructed cycle appears to be consistent with consumption-smoothing behavior, at least in the cases of Chile and Colombia. Figure Al. plots the actual real exchange rate alongside the permanent component. When the actual is below equilibrium the real exchange rate is "temporarily overvalued". This was the case for Chile during 1980-85 and again in 1991present. A similar pattern is evident in Colombia, with evidence of overvaluation prior to 1984 and in the post-1991 period. Consumptionsmoothing suggests that temporary overvaluations would be associated with wider current account deficits and increased capital inflows. In effect, these characteristics describe the periods mentioned fairly well. For Chile, during 1980-82 (the period with the largest suggested overvaluation), the current account deficit as a share of GDP averaged 10.4 percent. This was financed by capital inflows of similar orders of magnitude. By contrast, the 1986-1990 period recorded a current account deficit of 3.4 percent and capital outflows of 3.1 percent. During 1991-93, the current account continued to shrink, but the balance on the capital account swung markedly, with recorded inflows amounting to 5.7 percent of GDP. The pattern for Colombia is similar, although the swings are less pronounced. During 1980-82 capital inflows amount to 6 percent of GDP, these shrink to 0.7 percent during $1985-90$, and inflows accelerate in recent years, averaging 1.2 percent in 1991-93. $1 /$

With regard to the macroeconomic determinants of the permanent component of the real exchange rate, we proceed, as before, to examine if a cointegrating relationship can be detected among the "permanent" component and real GDP per capita (a proxy for output of nontraded goods), the inflation tax per capita, and the terms of trade. The results mimic those reported in Table 6 in both the presence (or absence) of cointegration and the signs on the coefficients for the two cases (Chile and Colombia) where a cointegrating equation is found. Interestingly, in the case of Chile where the terms of trade is a crucial variable, the relationship among the two relative prices appears to be between the permanent components of the real exchange rate and the terms of trade; their respective cycles are uncorrelated.

1/ It is important to note, that the figures for Colombia understate importantly the recent surge in capital inflows, as some of the capital inflows were being recorded as transfers in the current account. 
Figure A.1. Real Exchange Rates: Trends and Cycles
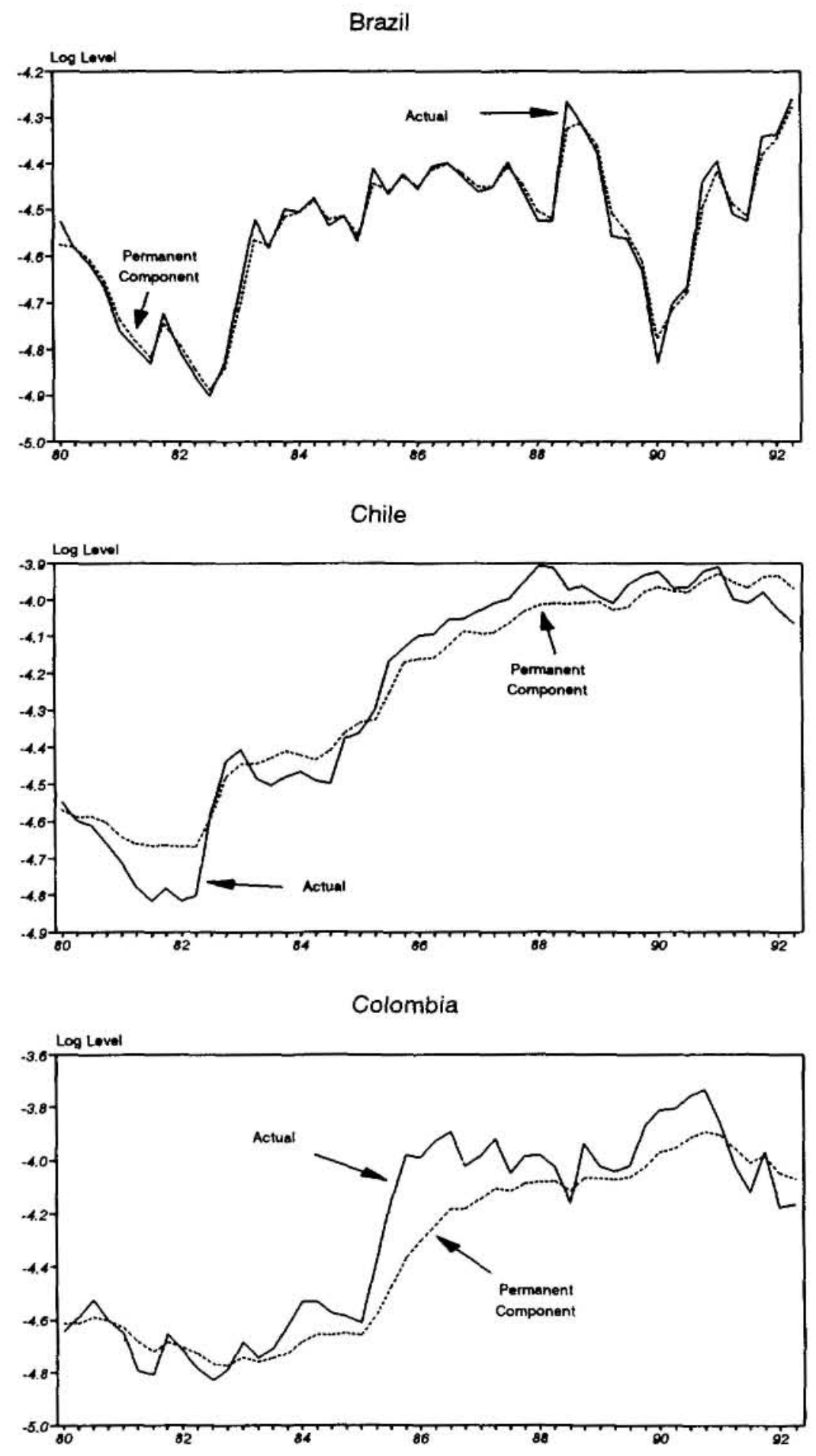

Source: IMF, International Financial Statistics and Fund staff estimates.

Note: A decrease in the real effective exchange rate index denotes an appreciation. Inflation is computed as the change in the CPI over the previous quarter for Brazil and over the previous four quarters for Chile and Colombia. 

Table A1. Beveridge-Ne1son Decompositions of the Real Exchange Rate

Modelling the change in the permanent component as an ARMA process 1 /

\begin{tabular}{|c|c|c|c|}
\hline Country: & Brazil & Chile & Colombia \\
\hline \multicolumn{4}{|c|}{ Quarterly: $1978 ;$ I-1992: } \\
\hline $\operatorname{ARMA}(p, q)$ & $\operatorname{ARMA}(1,0)$ & $\operatorname{ARMA}(4,3)$ & $\operatorname{ARMA}(5,1)$ \\
\hline Constant & $\begin{array}{l}-0.002 \\
(0.012)\end{array}$ & $\begin{array}{l}-0.003 \\
(0.392)\end{array}$ & $\begin{array}{c}0.001 \\
(0.015)\end{array}$ \\
\hline $\mathrm{AR}(1)$ & 0.234 & 1.688 & -0.303 \\
\hline $\mathrm{AR}(2)$ & $\begin{array}{l}(0.103) \\
* * * * * *\end{array}$ & $\begin{array}{l}(0.336) \\
-1.714 \\
(0.311)\end{array}$ & $\begin{array}{c}(0.286) \\
0.454 \\
(0.187)\end{array}$ \\
\hline $\mathrm{AR}(3)$ & $* * * * * *$ & $\begin{array}{l}1.644 \\
(0.359)\end{array}$ & $\begin{array}{c}0.122 \\
(0.170)\end{array}$ \\
\hline $\operatorname{AR}(4)$ & $\star \star \star \star \star \star \star *$ & $\begin{array}{l}-0.630 \\
(0.282)\end{array}$ & $\begin{array}{l}-0.024 \\
(0.159)\end{array}$ \\
\hline $\operatorname{AR}(5)$ & $\star \star * * * * \star$ & $\star * \star \star * \star * \star$ & $\begin{array}{c}0.206 \\
(0.062)\end{array}$ \\
\hline $\operatorname{MA}(1)$ & $\star \star \star \star \star \star * *$ & $\begin{array}{l}-1.265 \\
(0.416)\end{array}$ & $\begin{array}{c}0.742 \\
(0.284)\end{array}$ \\
\hline $\operatorname{MA}(2)$ & $\star \star \star * * * *$ & $\begin{array}{l}1.101 \\
(0.362)\end{array}$ & $\star \star \star \star * * * *$ \\
\hline $\operatorname{MA}(3)$ & $\star \star \star \star \star \star * *$ & $\begin{array}{l}-1.051 \\
(0.421)\end{array}$ & $\star * * * * *$ \\
\hline $\mathrm{R}^{2}$ & 0.164 & 0.304 & 0.333 \\
\hline $\begin{array}{l}\text { Q statistic } \\
\text { Significance level }\end{array}$ & $\begin{array}{l}20.571 \\
(0.485)\end{array}$ & $\begin{array}{l}17.304 \\
(0.693)\end{array}$ & $\begin{array}{l}12.447 \\
(0.927)\end{array}$ \\
\hline
\end{tabular}

1/ Standard errors are in parentheses. The models were estimated using log-differences. All series were allowed to have a breaks in their rates of change in 1985:I. The Q-statistics tests whether the regression residuals are white noise. The significance level is the probability that the actual Q-statistic value will be observed under the null hypothesis that the residuals are white noise. 


\section{$\underline{\text { References }}$}

Bacha, Edmar L., "Notes on the Brazilian experience with minidevaluations, 1968-1976", Journal of Development Economics 6, (1979), 463-481.

Beveridge, S., and C. Nelson, "A new approach to decomposition of economic time series into permanent and transitory components with particular attention to the measurement of the business cycle," Journal of Monetary Economics 7, (1981), 151-174.

Carrasquilla, A., "Estabilizacion macroeconomica y tasas de interes en Colombia: se agoto otro modelo?," mimeo, Banco de la Republica (Colombia), (1992).

Cochrane, J., "How big is the random walk in GNP?," Journal of Political Economy 96, (1988), 893-920.

Corbo, V., and A. Solimano, "Chile's experience with stabilization revisited," in M. Bruno, S. Fischer, E. Helpman, and N. Liviatan, eds., Lessons of economic stabilization and its aftermath, (Cambridge, Massachusetts: MIT Press, 1991), 57-91.

Edwards, S., Real exchange rates, devaluation, and adjustment, (Cambridge, Massachusetts: MIT Press, 1989).

Edwards, S., "Comments on: Chile's experience with stabilization revisited", in M. Bruno, S. Fischer, E. Helpman, and N. Liviatan, eds., Lessons of economic stabilization and its aftermath (Cambridge, Massachusetts: MIT Press, 1991), 92-98.

French-Davis, R., "Exchange rate policies in Chile: the experience with the crawling-peg," in J. Williamson, ed., Exchange rate rules (New York:

St. Martin's Press, 1981).

Fontaine, J.A., "La administración de la politica monetaria en Chile, 19851989," Cuadernos de Economia 28 (Chile), (1991), 109-129.

Guidotti, P.A., and C.A. Végh, "Macroeconomic interdependence under capital controls: a two-country model of dual exchange rates," Journal of International Economics 32, (1992), 342-367.

Herrera, S., "Qué tan grande es el desequilibrio cambiario en Colombia?," Ensayos sobre política económica 20 (Banco de la República, Colombia), $145-174$.

Johansen, S., "Statistical analysis of cointegrating vectors," Journal of Economic Dynamics and Control 12, (1988), 231-254.

-, "Estimation and hypothesis testing of cointegration vectors in Gaussian vector autoregressive models," Econometrica 59, (1991), $1551-1580$. 
Lizondo, J.S., "Real exchange rate targets, nominal exchange rate policies, and inflation," Revista de Análisis Económico 6, (1991), 5-22.

substitutability," Working Paper 93/38, IMF, (1993).

Miller, S., "The Beveridge-Nelson decomposition of economic time series: another economical computational method," Journal of Monetary Economics 21, (1988), 141-142.

Montiel, P.J. and J.D. Ostry, "Macroeconomic implications of real exchange rate targeting in developing countries," IMF Staff Papers 38, (1991), $872-900$.

- - - Real exchange rate targeting under capital controls: can money provide a nominal anchor?," IMF Staff Papers 39, (1992), 58-78.

Obstfeld, M., "Capital controls, the dual exchange rate and devaluation," Journal of International Economics 20, (1986), 1-20.

Osterwald-Lenum, M., "A note with quantiles of the asymptotic distribution of the maximum likelihood cointegration rank test statistic," Oxford Bulletin of Economics and Statistics 54, (1992), 461-469.

Ostry, J. and C.M. Reinhart, "Private saving and terms of trade shocks: evidence from developing countries," IMF Staff Papers 39, (1992), 495-517.

Reinhart, C.M. and C.A. Végh, "Nominal interest rates, consumption booms, and lack of credibility: a quantitative examination," mimeo, IMF, (1992).

- , - "Intertemporal consumption substitution and inflation stabilization: an empirical investigation," mimeo, IMF, (1993).

Roldos, J.E., "The terms of trade and the real exchange rate: theory an evidence," mimeo, University of Rochester, (1990).

Stock, J., and M. Watson, "A simple MLE of cointegrating vectors in higher order integrated systems," NBER Technical Working Paper 83, (1990).

Williamson, J., "The crawling peg in historical perspective," in J. Williamson, ed., Exchange rate rules (New York: St. Martin's Press, 1981).

- ed., Exchange rate rules (New York: St. Martin's Press, 1981). 
